\title{
İngiliz Konsolosluk Raporlarına Göre 93 Harbi Sonrası Erzurum Vilayeti'nde Sosyo-İktisadi Hayat (1878-1885)
}

\author{
Emel Demir Görür*
}

\section{$\ddot{\mathbf{O}}_{\mathbf{z}}$}

93 Harbi (1877-1878 Osmanlı-Rus Savaşı) sırasında Osmanlı Devleti'nin bazı toprakları işgal edilmiş, harp devletin hemen hemen tüm kurum ve kuruluşlarını olumsuz etkilemiştir. Bununla bağlantılı olarak özellikle savaşın cereyan ettiği bölgelerde iktisadi ve sosyal hayat olumsuz etkilenmiş, hatta durma noktasına gelmiştir.

93 Harbi sonrası Erzurum’un sosyo-iktisadi yapısı, Erzurum İngiliz Konsolosluğu görevinde bulunan Harry Charles Augustus Eyres, William Everett ve George Pollard Devey'in yazışmaları ve raporlarında geniş yer bulmuştur. Konsolos Augustus Eyres, Erzurum Vilayeti’nin ekonomik yapısı hakkında yıllardır rapor yazılmadığını ve vilayetin ekonomik yapısının ortaya çıkarılmasının önemli olduğunu belirterek özellikle 1880, 1881 ve 1882 yıllarına dair vilayetin sosyo-iktisadi yapısı ile ilgili ayrıntılı değerlendirmeler yapmış, önemli istatistiki bilgilere yer vermiştir. Konsolos William Everett 1882 ve 1883, Vekil Konsolos George Pollard Devey de, 1884 ve 1885 yıllarına dair vilayetin sosyo-iktisadi yapısına dair ayrıntılı değerlendirmelerde bulunmuşlardır. Her üç konsolos da raporlarında karşılaştırmalı bilgiler sunmuş özellikle savaş sonrası Erzurum Vilayeti'nin iktisadi ve sosyal hayatını kaleme almışlardır.

Çalışmada temel kaynak olarak kullanılan İngiliz Konsolosluk belgeleri, Erzurum Vilayeti ve çevresinde bulunan diğer yerleşim yerlerinin ekonomik ve bununla bağlantılı olarak sosyal yapısını ortaya koyacak önemli bilgiler ihtiva etmektedir.

Çalışma dâhilinde Erzurum Vilayeti'nin mevcut pazar durumu, yıllık gelirgider kalemleri, Fransa, Avusturya, Amerika, Almanya, İsviçre, İran, İngiltere, Rusya gibi doğulu ve batılı devletlerden ithal edilen ve Erzurum Vilayeti'nden de yabancı ülkelere ihraç edilen, ayrıca Van, Bitlis, Muş, Siirt, Diyarbakır, Mardin, Halep, Harput, Trabzon, Samsun, Rize, Erzincan, Arapkir, Ayntab, Bağdat, Karahisar, Palu ve Tokat'dan alınan ve bu bölgelere satılan ürünlerin miktarı ve piyasa değeri tablolar

* Dr., Dicle Üniversitesi, Ziya Gökalp Eğitim Fakültesi, Sosyal Bilimler ve Türkçe Eğitimi Bölümü, Diyarbakır/TÜRKIYE, emeldemirgorur@gmail.com ORCID: 0000-0003-1408-1377

Makale Gönderim Tarihi: 24.12.2018 - Makale Kabul Tarihi: 02.10. 2019 
halinde verilmiş ve bazı emtianın da önemine binaen ayrıntılı değerlendirmeleri yapılmıştır. Çalışmada Erzurum Vilayeti'nin savaştan ne kadar etkilendiğinin yanında dönem itibariyle vilayetin ticaret potansiyeli de gözler önüne serilmeye çalışılmıştır.

Anahtar Kelimeler: Erzurum Vilayeti, İngiliz Konsolosluğu, Harry Charles Augustus Eyres, William Everett, George Pollard Devey, sosyo-iktisadi hayat

\title{
Social-Economic Life in the Erzeroum Province after the Russo- Turkish War (1877-1878) according to the British Consular Reports
} (1878-1885)

\begin{abstract}
Some territory of the Ottoman Empire was occupied during Russo-Turkish War (1877-1878), and the war had a negative effect on almost all the state institutions. In this context, especially in regions where war took place, economic and social life was negatively affected and even came to a standstill. The subject of the study, the post-war socio-economic structure of Erzeroum, is located in the reports and correspondence of Harry Charles Augustus Eyres, William Everett and George Pollard Devey, who were the British Consulate in Erzeroum. Consul Augustus Eyres stated that the economic structure of Erzeroum province had not been reported for years and that it was important to reveal the economic structure of the province, and made detailed evaluations about the socio-economic structure of the province in 1880, 1881 and 1882 years. The Consul William Everett in 1882 and 1883, Vice-Consul George Pollard Devey in 1884 and 1885, made detailed evaluations of the province's socioeconomic structure. All three consuls presented comparative information in their reports, especially after the war, they wrote the economic and social life of Erzeroum province.

The English consular documents used as the basic source in this study contain important information that will reveal the economic and social structure of Erzeroum province and its surrounding settlements.

In this study, the market situation of Erzeroum province, annual income-expense items, imported from eastern and western states such as France, Austria, America, Germany, Switzerland, Iran, Britain, Russia, and exported to foreign countries; and the amount and market value of products purchased from cities such as Van, Bitlis, Moush, Seart, Diarbekir, Mardin, Alleppo, Kharpout, Trebizond, Rize, Erzinjan,
\end{abstract}


Arabkir, Ayntab, Baghdad, Kara-Hissar and sold to these regions were given in the tables and detailed evaluations were made based on the importance of some products. In this study, we tried to show not only how much the Erzeroum province was affected by the war but also the trade potential of the province.

Keywords: Erzeroum Province, British Consulate, Harry Charles Augustus Eyres, William Everett, George Pollard Devey, social-economic life

\section{Giriş}

Kafkasya ve İran'dan gelen büyük yolların Anadolu’ya açılan yegâne giriş kapısı konumunda olan Erzurum, ilk ve ortaçağlardan beri Anadolu'ya girme teşebbüsünde bulunan istila güçlerine karşı bölge müdafaasında önemli bir mevkie sahip olmuşturı. Mevkiinin askeri önemi dolayısılla Erzurum, tarih boyunca canlı bir ticaret merkezi olma özelliği kazanmışır². Stratejik açıdan da ehemmiyetli olan Erzurum, Batı Asya ve Akdeniz'e kadar uzanan Ipek yolu ticaretinin önemli bir uğrak merkezi idis. Ortaçă̆ Bizans ve İslam kaynaklarına göre Erzurum zengin, birçok milletten tüccarın bulunduğu, halı dokumacılığının yaygın olarak yapıldığı bir şehir durumundayd1*. Saltuklu ve Selçuklu Türkleri dönemlerinde mühim ticarî fonksiyona sahip olan Erzurum'a Türkistan ve Iran'dan gelen kervan yolları ulaşmakta, Erzincan, Sivas, Kayseri ve Konya'ya uğradıktan sonra, Akdeniz limanlarına ulaşmaktaydı. Bu güzergâhla bağlantılı olarak, Erzurum ve Bayburt üzerinden devam eden ikinci bir ticaret yolu, Trabzon İskelesine uzanıyordu. Söz konusu yollar üzerinden getirilen ticaret malları Erzurum-Erzincan, Kayseri-Aksaray üzerinden, Konya'ya taşınıyor; buradan Antalya ve Alanya İskelelerine veya yine Konya-Karaman, Adana ve Halep üzerinden Şam'a ulaştırılıyordu. Sivas-TokatAmasya üzerinden geçen diğer bir yol, Sinop Limanına ve Erzurum'dan Trabzon'a varmakta idi. Bu ticarî ilişkiler sonucu, Trabzon-Bayburt-Erzurum-Tebriz arasında işleyen kervan yolları ticaret hacmini giderek büyütmüştür ${ }^{5}$. Erzurum,

1 Besim Darkot, "Erzurum”, İslam Ansiklopedisi, c. IV., Milli Eğitim Bakanlığı Yayınları, Eskişehir 1997, s. 340.

2 Cevdet Küçük, "Erzurum”, DİA, c. XI, Türk Diyanet Vakfi Yayınları, İstanbul 1995, s. 326.

3 Bilgehan Pamuk, "İpekyolu Ticareti ve Erzurum", Tarih İncelemeleri Dergisi, c. XXII, S. 2, Aralık 2017, s. 126.

4 Cevdet Küçük, "Erzurum”, s. 326.

5 Firdevs Temizgüney, Erzurum’a Demiryolunun Gelişi, Yüksek Lisans Tezi, Atatürk Üniversitesi Sosyal Bilimler Enstitüsü, Erzurum 2008, s. 43. 
Osmanlı hâkimiyeti altında da Anadolu ve Karadeniz'den Iran'a giden askeri ve ticarî yol üzerinde başlıca merkez olma karakterini muhafaza etmiştir ${ }^{\text {. }}$ Bu noktada Erzurum'un içinde bulunduğu Osmanlı Devleti'nin Trabzon-Erzurum-Tebriz yolu ile Rusya'nın Gürcistan kıylarındaki Sohum, Poti limanlarından hareketle uzandıkları Tiflis-Tebriz yolu sürekli mücadele halinde olmuşlardır?.

93 Harbi sonrası Erzurum Vilayeti’nin sosyo-iktisadi yapısının ele alındığı çalışmada Erzurum Vilayeti'nde görev yapan üç ayrı İngiliz Konsolosunun hazırladığı rapor ve yazışmalar kullanılmıștır. Harp sonrası hazırlanan raporlar, Erzurum Vilayeti ve çevresinde bulunan diğer yerleşim yerlerinin ekonomik ve bununla bağlantılı olarak sosyal yapısını ortaya koyacak önemli bilgiler ihtiva etmekte, vilayetin harp öncesi ve sonrası ekonomik ve sosyal yapısını karşılaştırmalı bir bakış açısıyla ortaya koyması hasebiyle önem arz etmektedir. Her ne kadar raporlar 1883, 1884, 1886 yıllarında yani savaştan bir süre sonra kaleme alınmış olsalar da, içerik olarak savaş öncesi döneme dair bilgiler de içermektedirler.

Ele aldığımız ilk rapor Erzurum İngiliz Konsolosu Harry Charles Augustus Eyres'in' hazırlamış olduğu 1883 tarihli rapordur. Rapor 1880, 1881, 1882 yılı Erzurum Vilayeti'nin sosyo-iktisadi hayatı hakkında ayrıntılı bilgiler sunmaktadır'. Bu rapor, 93 Harbi'nden sonra İngiliz Konsolosluğunca Erzurum'a dair hazırlanan ilk ticaret raporudur ${ }^{10}$. Araştırmamızda tespit ve izlenimlerinden yararlandığımız

6 Halil İnalcık, "Erzurum”, İslam Ansiklopedisi, c. IV, Milli Eğitim Bakanlığı Yayınları, Eskişehir 1997, s. 354.

7 Hüseyin Kaleli, "19. Yüzyllda İran Transit Ticaret Yolu İçin Osmanlı-Rus Rekabeti”, Dumluprnar Üniversitesi Sosyal Bilimler Dergisi, sy. 9, 2003, ss. 2-3

8 Harry Charles Augustus Eyres, 11 Ekim 1882'de İngiltere'nin Van Vilayeti Yardımcı Konsolosu olarak atanmıştır. 12 Kasım 1882'de Erzurum Vekil Konsolosluğuna atanmış bu görevini 3 Temmuz 1883'e kadar sürdürmüştür. 8 Temmuz 1885'de Beyrut Yardımcı Konsolosluğuna atanmıştır. Bkz; The Foreign Office List: Forming a Complete Diplomatic and Consular Handbook for 1886, Compiled by Edward Hertslet, G.B., Fifty-ninth Publication, London, p. 96; The London Gazette, Publication Date: 22 September 1882, Issue: 25149, Page: 4340; The London Gazette, Publication Date: 4 Ağustos 1885, Isuue: 25497, Page: 3599. Foreign Office Listlerde Eyres'in Erzurum'daki görevinden 3 Temmuz 1883'de ayrıldığını belirtmesine rağmen konsolosun en son gönderisini 12 Temmuz 1883'de yazdığı görülmektedir. Bkz; The National Archives (TNA.), Foreign Office (F.O.) 195/1450, No. 21, Harry Charles Augustus Eyres'den G.H. Wyndham'a, 12 Temmuz 1883, s. 97.

9 TNA., F.O. 195/1450, No. 21/1, Harry Charles Augustus Eyres'den G.H. Wyndham'a, 12 Temmuz 1883, ss. 99-120.

10 Konsolos Eyres, kendi raporundan önce 1875 yllında Erzurum'a dair bir ticaret raporunun yazıldığını ancak rapora ulaşılamadığı bilgisini vermiştir. Bkz; TNA., F.O. 195/1450, No. 21 / 1, Harry Charles Augustus Eyres'den G.H. Wyndham'a, 12 Temmuz 1883, s. 99. 
diğer İngiliz Konsolosu, William Everett'tir" ${ }^{\prime \prime}$ Everett'in Erzurum'a dair hazırlamış olduğu rapor Haziran 1884'de kaleme alınmıştır. Rapor, Erzurum Vilayeti'nin yanı sıra Van, Hakkâri, Diyarbakır ve Harput'un sosyo-iktisadi yapısına dair kapsamlı bilgiler ihtiva etmektedir ${ }^{12}$. Çalışmamızda tespitlerinden yararlandığımız diğer bir İngiliz Konsolosu, vekil konsolos yetkisiyle Erzurum'da bulunan George Pollard Devey'dir'³. Devey'in Temmuz 1886'de kaleme aldığı raporu 1884 ve 1885 yılları Erzurum Vilayeti'nin sosyo-iktisadi yapısına dair önemli bilgiler vermektedir ${ }^{14}$. Zira Mübahat Kütükoğlu, Avrupa devletleri konsoloslarının Erzurum Vilayeti ölçeğinde Osmanlı ticaretini kara gümrüklerinde tutulan defterlerinden takip etmiş olduklarına ve Avrupa Arşivlerinde bulunan bu tür raporların Osmanlı ticaret hacmi hakkında önemli bilgiler ihtiva ettiğine işaret etmiştiris.

Çalışma temel olarak İngiliz Konsolosları Eyres, Everett ve Devey’in rapor ve yazışmaları doğrultusunda ele alınmıştır.

\section{93 Harbi Sonrası Erzurum Vilayeti'nin İktisadi Durumu}

93 Harbi $^{16}$ sonrası Erzurum Vilayeti'nin iç ticaretinde durgunluk yaşanmıştır. Yerli tüccarlar, talepler doğrultusunda temel gereksinim maddeleri dışında

11 Lieutenant-Colonel (Yarbay) William Everett, 28 Ocak 1864'de orduya girmiş, 11 Ocak 1867'de teğmen, 9 Eylül 1874'de yüzbaşı, 1 Temmuz 1881'de binbaşı, 21 Şubat 1883'de yarbay (lokal) olmuştur. 2 Nisan 1879'da Bulgar sınırına, sınır belirlemek için görevlendirilen Majestelerinin komisyonuna asistan olarak atanmıştır. 11 Eylül 1882'de Van, Muş, Diyarbakır, Harput, Erzurum Paşalıklarını içine alan bölgeye Kürdistan Konsolosu olarak atanmıştır. Bkz; The Foreign Office List: Forming a Complete Diplomatic and Consular Handbook for 1887, Compiled by Edward Hertslet, C.B., Sixtieth Publication, London, p. 95.

12 TNA., F.O. 195/1481, No.1, William Everett'den Dufferin'e, 10 Haziran 1884, ss. 223-245. Çalışmamızın kapsamı gereği yalnızca raporun Erzurum Vilayeti ile ilgili kısmı değerlendirilecektir. Raporun Van Vilayeti ile ilgili kısmı için bkz; ss. 245-251; Hakkâri için bkz; ss. 251- 253; Diyarbakır için bkz; ss. 254- 263; Harput için bkz; ss. 263- 267.

13 George Pollard Devey, 25 Ağustos 1885'de Erzurum'a Vekil Konsolos olarak atanmıs, bu görevini 21 Ekim 1887'ye kadar sürdürmüştür. 1 Nisan 1887'de Çanakkale Yardımcı Konsolosluğu’na atanmıștır. Bu görevini 1 Nisan 1887 kadar sürdürmüştür. 7 Temmuz 1888'de Van Vilayeti Yardımcı Konsolosluğuna atanmıştır. Bkz; The Foreign Office List: Forming a Complete Diplomatic and Consular Handbook for 1889, Compiled by Edward Hertslet, C.B., Sixty-second Publication, London, p. 89.

14 TNA, F.O. 195/1552, No. 6/1, George Pollard Devey'den Sir E. Thornton'a, 16 Temmuz 1886, s. 90-99.

15 Mübahat S. Kütükoğlu "Gümrük", Diyanet Vakfi İslam Ansiklopedisi, c. XIV, Türk Diyanet Vakfi Yayınları, İstanbul 1996, s. 267.

1693 Harbi olarak adlandırılan 1877-1878 ylllarında cereyan eden bu savaş Kafkasya ve Tuna cephesi olmak üzere iki cephede cereyan etmiştir. Rus kuvvetleri, Osmanlı askeri kuvvetinin az 
herhangi başka bir ürün tedarik etmemişler, edememişlerdir. Toprağın değeri, Rusya'nın işgal ettiği topraklarda ağır kayıpların yaşanması, Rusya'nın sınıra dayanması ve sınırda kalan Müslüman halkın kendini güvende hissetmemesi nedeniyle harp öncesi ile kıyaslandığında 4'te 1 oranında azalmıştır. Evlerin fiyatları ise gerçek değerlerinin yarısını hatta daha aşağısına gerilemiştir. Harp öncesi dönemde bir evin maliyeti yaklaşık $1.100 £^{{ }^{17}}$ değerindeyken 1883 yllında ev fiyatları yaklaşık $450 £$ ’e düşmüştür.

Harp sonrasında işgal ordusunun yerli tüccarlardan aldıkları ürünler için ödedikleri abartılı paralar şehirde bir miktar sermayenin birikimi sağlamışsa da Konsolos Eyres, sermayenin yavaş yavaş tükendiğini, ticarette tam anlamıyla durgunluk yaşandığını belirtmiştir. Avrupalı tüccarlar ise pamuklu ürünler haricinde Erzurum pazarında çok az ticaret imkânı bulmuşlardır. 1873 yılı Erzurum'u ile 1883 yılı Erzurum’u karşılaştırıldığında 1873 yılında dükkânların emtia çeşitliliği ve stok bakımından daha iyi durumda olduğu, savaş sonrası dönemde dükkânlarda sadece zorunlu ihtiyaç mallarının bulundurulduğu, tüccarların nüfusun yoksullaşması, satış zorluğu gibi nedenlerle pahalı ithal malları tedarik etmedikleri görülmüştür. Bu duruma ek olarak İran ulaşımının kısmi kaybı Erzurum'u oldukça olumsuz etkilemiş, 1880 transit ticaret geliri 1870'e göre dörtte bir oranında azalmıştır. Bu azalmanın nedenlerinden biri Poti ve Batum'dan Tiflis'e yeni demiryolunun yapılması, ticaret güzergâhının yön değiştirmesidirı ${ }^{\text {s. }}$

olmasından istifade ile muharebeyi kazanmış ve Bayezid, Ruslar tarafindan işgal edilmiştir. Kısa süre içinde toparlanan Doğu Cephesi Komutanı Ahmet Muhtar Paşa komutasındaki Osmanlı kuvvetleri, Ruslara karşı üstünlük kurarak Rusları Kafkaslara kadar geriletmiş̧ir. Ancak Ahmet Muhtar Paşa, 1877 yılı sonları itibariyle Rusların Erzurum'a kadar gelmelerine engel olamamıştır. Osmanlı ordularının batı cephesindeki yenilgisi üzerine Ruslar doğuda Erzurum, batıda da İstanbul önlerine kadar ilerlemişlerdir. Kars'ın düşmesinden sonra İstanbul "Anadolu'nun Kilidi" dediği Erzurum'un müdafaasına hayati bir ehemmiyet vermiştir. Ancak Ruslarla yapılan muahede ile Erzurum'daki kuvvetlere Bayburt ve havalisine çekilmeleri emri verilmiştir. Bu emir ile Erzurum, kışlamak üzere Rus Ordusuna bırakılmıştır. 13 Temmuz 1878 tarihli Berlin Muahedesi ile Bab-1 Âli Kars, Ardahan ve Batum'u Rusya'ya terk etmiştir. Böylelikle Erzurum, sınırın hemen 10 km kadar içerisinde düşmanın ilk hücumuna maruz bir hudut kalesi durumuna düşmüştür. Bkz; Mahmud Celaleddin Paşa, Mirâtı ı Hakikat, haz. İsmet Miroğlu, c. II, Berekât Yayınları, İstanbul 1983, ss. 343-344; Rifat Uçarol, Siyasi Tarih (1789-2010), 8. Baskı, Der Yayınları, Ístanbul 2010, s. 375; Halil İnalcık, "Erzurum”, İslam Ansiklopedisi, c. IV, Milli Eğitim Bakanlığı Yayınları, Eskişehir 1997, ss. 356.

17 İngiltere’nin Diyarbakır Konsolosu John George Taylor, 1864 yılında hazırladığı raporunda 1 sterlinin 110 kuruşa tekabül ettiğini belirtmiştir. Bkz; Emel Demir Görür, "İngiltere'nin Diyarbakır Konsolosu John George Taylor'ın Diyarbakır Eyaleti'ne Dair İthalat-İhracat İstatistikleri ve Değerlendirmeleri (1853-1863)", TAD, c. 37, S. 64, 2018, s. 328.

18 Poti-Tiflis demiryolu 1871 yılında bitirilmiştir. İlk yolcular 1872 yılında taşınmıştır. Bkz; Abdullah 
Ancak bu demiryolu hattının açılmasından önce de Erzurum'dan İran'a devam eden yolun güvensiz ve kötü olması hasebiyle ticarette büyük düşüşler yaşanmıştır.

Bölge halkının geçim kaynaklarına bakıldığında demircilik mesleği ile uğraşanların sayıca fazla olduğunu görülmektedir. Demirciliğin yanı sıra kürkçüler, dericiler, tabakçılar, halıcılar, yün temizleyiciler, kilitçiler ve saraçlar Konsolos Eyres'in raporunda bahsettiği diğer meslek gruplarıdır.

Erzurum pazarındaki fiyatlar yıldan yıla hasattaki bolluk ya da verimsizlik gibi nedenlerle değişiklik göstermiştir. Ancak fiyatların genellikle sabit kaldığı görülmüştür.

Tablo 1: Erzurum Vilayeti'nde ortalama pazar fiyatlar1 $1^{19}$

\begin{tabular}{|l|l|l|l|l|}
\hline \multirow{2}{*}{ Ürün } & \multirow{2}{*}{ Ölçü/Ağırlık } & \multicolumn{3}{|c|}{ Fiyat } \\
\cline { 3 - 5 } & & $£$ & $\mathrm{~S}^{20}$ & $\mathrm{D}^{21}$ \\
\hline Ekmek & Her okkas1 ${ }^{22}\left(2^{3 / 4} \mathrm{lbs}\right)$ & 0 & 0 & 2 \\
\hline Siğır eti & Her okkası & 0 & 0 & 3 1/2 \\
\hline Koyun eti & Her okkası & 0 & 0 & 5 \\
\hline Tavuk, hindi, ördek eti & Her biri & 0 & 0 & 4 \\
\hline Yakacak odun (yazın) & Her cwt ${ }^{23}$ & 0 & 2 & 0 \\
\hline Yakacak odun (kışın) & Her cwt & 0 & 3 & 2 \\
\hline Kömür (yazın) & Her cwt & 0 & 3 & 8 \\
\hline
\end{tabular}

Bay, "Limanı Olan Bir Kasabadan Liman Kentine: Batum Şehri (1830-1905)”, Türkiyat Mecmuası, c. 26/1, 2016, s. 74; Gülpınar Akbulut Özpay, "Bakü-Tiflis-Kars Demiryolu ve Türkiye Açısından Jeopolitik Önemi”, Marmara Coğrafya Dergisi, S. 37, Ocak 2018, s. 108.

19 TNA., F.O. 195/1450, No. 21/1, Harry Charles Augustus Eyres'den G.H. Wyndham'a, 30 Haziran 1883, s. 112.

20 Shilling-Şilin (s), İngiltere'nin ondalık sisteme geçişten önce kullanılan bir para birimidir. Şilin, 1 sterlinin 1/20'sine denk gelmektedir. Bkz; Marjie Bloy, "British Currency Before 1971", http:// www.victorianweb.org/economics/currency.html (14.09.2018).

21 Penny (d), 12 penny bir şiline, 240 penny, 1 sterline denk gelmektedir. Bkz; Bloy, 2017

22 Okka/ûkıyye, 1283 gramlık ağırlık ölçüsüdür. Bkz; Ferit Devellioğlu, Osmanhca-Türkçe Ansiklopedik Lûgat, 17. bs., Aydın Kitabevi, Ankara 2000, s. 1118; İngiliz Konsolos Eyres, bir okkanın 2 lbs 13 oz’a tekabül ettiğini belirtmiştir. Bkz; TNA., F.O. 195/1450, No. 21/1, Harry Charles Augustus Eyres'den G.H. Wyndham'a, 12 Temmuz 1883, s. 107.

23 Cwt, İngiltere'de 50.8, Amerika'da 45.35 kilograma denk gelen ağılık ölçü birimidir. https:// dictionary.cambridge.org/tr/s $\% \mathrm{C} 3 \% \mathrm{~B} 6 \mathrm{zl} \% \mathrm{C} 3 \% \mathrm{BCk} /$ ingilizce-t $\% \mathrm{C} 3 \% \mathrm{BCrk} \% \mathrm{C} 3 \% \mathrm{~A} 7 \mathrm{e} / \mathrm{cwt}$ (11.12.2018) 


\begin{tabular}{|l|l|l|l|l|}
\hline Kömür (kışın) & Her cwt & 0 & 7 & 0 \\
\hline Patates & Her batman1 ${ }^{24}\left(16^{1 / 2} \mathrm{lbs}\right)$ & 0 & 0 & 6 \\
\hline Soğan & Her batmanı & 0 & 0 & 3 \\
\hline Üzüm & Her batmanı & 0 & 1 & 7 \\
\hline Dĭger meyveler & Her batmanı & 0 & 1 & 6 \\
\hline Pancar & Her batmanı & 0 & 0 & 8 \\
\hline Turp & Her batmanı & 0 & 0 & 3 \\
\hline
\end{tabular}

Konsolos Eyres, bir vatandaşın Erzurum'da yaşama maliyetinin çok yüksek olmadığını sadece yakacak odun fiyatının fahiş olduğunu bununda vilayete en yakın ormanın yaklaşık 8 saat uzaklıkta olmasından kaynaklandığını belirtmiştir. Odun alacak güce sahip olmayan halk yakacak olarak tezek kullanmıștır. Zorunlu tüketim mallarının ucuz olduğu vilayette Avrupa'dan ithal malların fiyatları uzaklık, nakliye masrafi gibi nedenlerle iki misline çıkmıştır.

Tablo 2: Erzurum Vilayeti'nin bir yıllık pazar hasılatı

\begin{tabular}{|l|l|l|}
\hline Ürün & Miktar & Değer (£) \\
\hline Buğday, arpa, çavdar (ekmek yapımı için) & --- & 140.000 \\
\hline Arpa (hayvanlar için) & --- & 15.000 \\
\hline Tereyağı & --- & 18.000 \\
\hline Yakıt & --- & 40.000 \\
\hline Kereste & --- & 13.000 \\
\hline Öküz & 12.000 & 24.000 \\
\hline Koyun & 50.000 & 25.000 \\
\hline Keçi & & \\
\hline Siğır & 1.000 & 4.500 \\
\hline Peynir & --- & 3.000 \\
\hline Kurutulmuş Meyve & --- & 2.000 \\
\hline \multicolumn{2}{|l}{ Toplam } & $284.500^{25}$ \\
\hline
\end{tabular}

24 Batman ölçü biriminin zaman ve mekâna göre ağırlık değeri değişmiştir. 1650 yllında Erzurum da bir batman 7.83 kg. denk gelmiştir. Bkz; Cengiz Kallek, "Batman", Diyanet Vakfi İslam Ansiklopedisi, Cilt: V, Türk Diyanet Vakfi Yayınları, İstanbul 1992, ss. 199-120.

25 Toplam miktar $285.500 £$ olması gerekirken, tabloda toplam hasılat $302.500 £$ olarak yazılmışır Bkz; TNA., F.O. 195/1450, No. 21/1, Harry Charles Augustus Eyres'den G.H. Wyndham'a, 30 
Bölgede en fazla ticareti yapılan, gelir getiren ürün tahıldır. Tahıldan sonra ise küçükbaş hayvan ticaretinin gelir getirdiği, en düşük payı ise $2.000 £$ değeriyle kurutulmuş meyvenin oluşturduğu görülmektedir. Erzurum'un yaklaşık 1 ylllık pazar hasilat1 $284.500 £^{\prime}$ dir $^{26}$.

Tablo 3: 1881 yll Erzurum Vilayeti'nin gelirleri

\begin{tabular}{|l|l|}
\hline Gelir Türü & Kuruş \\
\hline Mal ve Gelir Vergisi & 4.282 .577 \\
\hline Bedel-i Askeriye & 1.462 .568 \\
\hline Aşar & 10.597 .582 \\
\hline Ağnam Vergisi & 2.178 .074 \\
\hline Orman Geliri & 76.000 \\
\hline Adli Harçlar & 506.258 \\
\hline Tapu & 289.726 \\
\hline Bazı diğer harcamalar & 345.588 \\
\hline Toplam & 19.738 .373 \\
\hline
\end{tabular}

Tablo 4: 1881 y1l Erzurum Vilayeti'nin giderleri²7

\begin{tabular}{|l|l|}
\hline Gider Türü & Kuruş \\
\hline İdare & 6.208 .307 \\
\hline Mali & 4.281 .255 \\
\hline Kadı ve Müftünün Maaşları & 275.934 \\
\hline Adli & 974.492 \\
\hline Maarif & 85.492 \\
\hline Bayındırlı Hizmetleri-Nafia & 396.828 \\
\hline Karantina & 960 \\
\hline Toplam & 12.223 .268 \\
\hline
\end{tabular}

Haziran 1883, s. 113.

26 TNA., F.O. 195/1450, No. 21/1, Harry Charles Augustus Eyres'den G.H. Wyndham'a, 30 Haziran 1883, ss. 112-113.

27 TNA., F.O. 195/1450, No. 21/1, Harry Charles Augustus Eyres'den G.H. Wyndham'a, 30 Haziran 1883, s. 118. 
1881 yılı bütçesinde gelir-gider dengesi gözetildiğinde 7.515.105 kuruş artan olduğu görülmektedir. Konsolos Eyres, memur maaşlarının oldukça düzenli ödendiğini, askerlerin maaş ödemelerinde ise gecikmeler olduğunu belirtmiştir. Ayrıca Konsolos Eyres raporunda vilayet hazinesinin tükendiğini, yerel hükümetin merkezi hükümetin desteğine ihtiyaç duyduğunu yazmıştı².

Tablo 5: 1882 yılı Erzurum Vilayeti'nin gelirleri

\begin{tabular}{|l|l|}
\hline Gelir Türü & Kuruş \\
\hline Mal ve Gelir Vergisi & 4.077 .954 \\
\hline Bedel-i Askeriye & 1.450 .597 \\
\hline Aşar & 9.693 .882 \\
\hline Ağnam Vergisi & 3.349 .601 \\
\hline Diğer & 1.068 .028 \\
\hline Toplam & 19.640 .062 \\
\hline
\end{tabular}

Tablo 6: 1882 yılı Erzurum Vilayeti’nin giderleri

\begin{tabular}{|l|l|}
\hline Gider Türü & Kuruş \\
\hline İdare & 5.010 .918 \\
\hline Mali & 4.496 .902 \\
\hline Kadı ve Müftü Maaşları & 293.934 \\
\hline Adli & 974.492 \\
\hline Maarif & 129.194 \\
\hline Bayındırlık Hizmetleri-Nafia & 755.500 \\
\hline Karantina & 960 \\
\hline Toplam & 11.661 .900 \\
\hline
\end{tabular}

1882 yllında bayındırlık hizmetleri için harcanan miktar 1881 yllı ile karşılaştırdığımızda neredeyse iki misline çıkmış, yaklaşık sekiz milyonluk kalan ise korunmuştur. Harcamaların artmasına rağmen kalanın korunması 1882 ağnam vergisi ve diğer çeşitli gelirlerden kaynaklanmıştır².

28 TNA., F.O. 195/1450, No. 21/1, Harry Charles Augustus Eyres'den G.H. Wyndham'a, 30 Haziran 1883, ss. 99-120.

29 TNA., F.O. 195/1450, No. 1/1, William Everett'den G.H. Wyndham'a, 31 Temmuz 1883, ss. 184-185. 
Tablo 7: 1883 Erzurum Vilayeti'nin gelirleri

\begin{tabular}{|l|l|}
\hline Gelir Türü & Kuruş \\
\hline Mal ve Gelir Vergisi & 4.122 .237 \\
\hline Bedel-i Askeriye & 1.413 .075 \\
\hline Aşar & 14.444 .297 \\
\hline Ağnam Vergisi & 3.616 .637 \\
\hline Damga resmi & 946.136 \\
\hline Ayrı gelir & 449.380 \\
\hline Diğer & 161.380 \\
\hline Toplam & 25.153 .142 \\
\hline
\end{tabular}

Tablo 8: 1883 yılı Erzurum Vilayeti'nin giderleri

\begin{tabular}{|l|l|}
\hline Gider Türü & Kuruş \\
\hline Dâhili ve jandarma & 5.149 .608 \\
\hline Mali & 4.603 .314 \\
\hline Din görevlilerin maaşları & 395.939 \\
\hline Adli & 994.620 \\
\hline Maarif & 129.194 \\
\hline Kamu Harcamaları & 783.800 \\
\hline Karantina & 960 \\
\hline Toplam & 12.057 .435 \\
\hline
\end{tabular}

1883 yılı gelirin bir önceki yıla göre, aşar ve ağnam vergileri nedeniyle yaklaşık 5.000 kuruş arttığı görülmektedir. Vilayetin gelir ve giderlerine dair bilgiler konsoloslar tarafindan yerel hükümetten alınmıştır. Gelir ve gider tabloları valinin nezaretinde hazırlanmıştır ${ }^{30}$. 
Tablo 9: Erzurum Vilayet Salnâmesine göre 1875 (1293) yılı vilayetin gelirleri

\begin{tabular}{|l|l|}
\hline Gelir Türü & Kuruş \\
\hline Vergi & 7.273 .479 \\
\hline Fazla Vergi & 190.604 \\
\hline Bedel-i Askeri & 2.792 .197 \\
\hline Gayr ez Rub-1 Öşr-i Adînin Bedelat-1 Maktuası & 17.809 .873 \\
\hline Kezalik Rub-1 Öşr Emaneti & 298.068 \\
\hline Öşr-i Duhan ve Çiriş ve Harir & 51.343 \\
\hline Hâsllat-1 Ağnam & 11.035 .924 \\
\hline Resm-i Orman & 271.892 \\
\hline Varidat-1 Rüsumiye & 1.415 .732 \\
\hline Rüsumat Emaneti & 13.623 \\
\hline İskonto & 206.769 \\
\hline Harc-1 Vesaik ve Mezabit ve Resm Tahsili ve saire & 384.900 \\
\hline Toplam & $\mathbf{4 1 . 7 4 5 . 3 0 4}$ \\
\hline
\end{tabular}

Erzurum Vilayeti’nin 1875 (1293) yllı gelirlerini ileriki yıllar ile karşılaştırdığımızda 93. Harbi öncesi hasılatın fazla olduğu görülmektedir. Ancak o dönem itibariyle Erzurum Vilayeti’ne Erzurum, Bayburt, Pasinler, İspir, Hınıs, Tercan, Kiğı, Erzincan, Çıldır, Muş, Van, Kars, Bayezid Sancaklarının dâhil olduğu gözden kaçırılmamalıdır ${ }^{31}$.

\section{Erzurum Gümrüğü}

Osmanlı idaresi altında Erzurum gümrüğünün ne zaman faaliyete geçtiği konusunda kaynaklarda kesin bir bilgi olmamakla birlikte XVI. yüzyılın son çeyreğinde gümrükle ilgili verilere rastlanmaktadır. Erzurum gümrüğü teşkil olduktan sonra transit ticaret daha kontrollü ve verimli işletilmeye çalışılmış, bir taraftan ticarî potansiyel artırılırken, diğer taraftan da ticarî bakımdan stratejik yerler kontrol altına alınmıştır ${ }^{32}$. 19. yüzyılda Kars ve Ardahan gibi bazı komşu gümrükler de Erzurum gümrügüne bağlanmıştır. Erzurum gümrüğü,

31 Salnâme-i Vilâyet-i Erzurum, H. 1293 (M. 1876), Def'a 7, s. 138; Yakup Karataş, Sultan II. Abdülhamid Dönemi’nde Erzurum (Sosyal, Ekonomik, İdarî ve Demografik Yapi), Doktora Tezi, Atatürk Üniversitesi Sosyal Bilimler Enstitüsü, Erzurum 2010, s. 118.

32 Bilgehan Pamuk, "Erzurum Gümrüğü’nün Teşekkülü ve Tekâmülü (XVI-XVII Yüzylllar)", Belleten, Cilt: LXXVII, S. 279, Ağustos 2013, ss. 525-526. 
Sultan II. Mahmud tarafindan Erzurum redif-i mansure hazinesine aktarılmış, bağlı gümrüklerle birlikte 1832-1833’te 544.985 kuruş gelir getirmiştir. Diğer bazı gelirlerle beraber bu rakam 569.868 kuruşa ulaşmış, bu gelirlerin tamamı Erzurum'daki askerin maaş ve aylık masraflarına tahsis edilmiştir. Tanzimat'ın uygulanmasından sonra ise Erzurum'un gelirleri azalmaya başlamıştır. Ayrıca 1830-1840 yıllarında Kafkaslara yerleşen Rusların 19. yüzyıl sonlarına doğru Güney Kafkasya demiryollarını inşa etmeleri ve özellikle Culfa-Batum hattı, Erzurum'un İran transit ticaretinden elde ettiği gelirleri önemli ölçüde etkilemiştir. Buna rağmen yine de en önemli gelir kaynağı gümrük gelirleriydi. Erzurum tüccarlarının depolanmasından ve nakliyatından büyük gelir elde ettikleri transit emtianın yıllık ortalama miktarı 12-16 ton arasında değişmiştiri³.

Tablo 10: 1880, 1881, 1882 yılı Erzurum Gümrüğünün gelir ve giderleri³ ${ }^{34}$

\begin{tabular}{|l|l|l|l|}
\hline & 1880 (Kuruş) & 1881 (Kuruş) & 1882 (Kuruş) \\
\hline Gelir & 1.865 .197 & 1.137 .895 & 1.557 .468 \\
\hline Gider & 398.002 & 422.296 & 474.162 \\
\hline Bakiye & 1.467 .195 & 715.599 & 1.083 .306 \\
\hline
\end{tabular}

1880 yılı gümrük gelirini 1881 yılı ile karşılaştırdığımızda 1881 yılı gelirlerinde yaklaşık 700.000 kuruş azalma olduğu görülmektedir. Bu azalmanın nedeni ise 1881 yılında İran tütününde gümrük resminin kalkmasıdır. Konsolos Eyres, 1883 yılında transit ticarette İran'dan gelen emtiadan gümrük resmi alınmadığı belirtmiştir.

Tablo 11: Erzurum Gümrüğü’nde ithal ürünlerde ödenen vergi

\begin{tabular}{|l|l|l|l|l|l|l|}
\hline \multirow{2}{*}{ Ülke } & \multicolumn{2}{|c|}{1880} & \multicolumn{2}{c|}{1881} & \multicolumn{2}{c|}{1882} \\
\cline { 2 - 7 } & Balya & Değer $(£)$ & Balya & Değer $(£)$ & Balya & Değer $(£)$ \\
\hline Rusya'dan & 1.878 & 19.183 & 1.157 & 14.755 & 2.929 & 27.527 \\
\hline İran'dan & 8.860 & 25.710 & 3.523 & 95.883 & 6.562 & 113.286 \\
\hline Avrupa'dan & 250 & 15.755 & 81 & 223 & 29 & 374 \\
\hline Toplam & 10.988 & 60.648 & 4.761 & 110.861 & 9.520 & 141.187 \\
\hline
\end{tabular}

33 Cevdet Küçük, "Erzurum”, s. 327.

34 TNA., F.O. 195/1450, No. 21/1, Harry Charles Augustus Eyres'den G.H. Wyndham'a, 30 Haziran 1883, s. 119. 
Tablo 12: Erzurum Gümrüğü'nde ihracat ürünlerinde ödenen vergi ${ }^{35}$

\begin{tabular}{|l|l|l|l|l|l|l|}
\hline \multirow{2}{*}{ Ülke } & \multicolumn{2}{|c|}{1880} & \multicolumn{2}{c|}{1881} & \multicolumn{2}{c|}{1882} \\
\cline { 2 - 7 } & Balya & Değer $(£)$ & Balya & Değer $(£)$ & Balya & Değer $(£)$ \\
\hline Rusya'ya & 1.768 & 13.130 & 2.436 & 12.764 & 2.277 & 15.301 \\
\hline İran'a & 10 & 31 & 34 & 98 & 146 & 445 \\
\hline Toplam & 1.778 & 13.161 & 2.470 & 12.862 & 2.423 & 15.746 \\
\hline
\end{tabular}

\section{Galata Bankerlerine Devredilen Katkı Payı}

Galata Bankerlerinin Erzurum Vilayeti'nde aldıkları katkı paylarına geçmeden önce kısaca Osmanlı Devleti'nin borçlanması ve Rüsum-ı Sitte İdaresinin kuruluşu ve işleyişine değinmenin konunun anlaşılması açısından daha iyi olacağı düşünülmektedir.

Kırım Savaşı'nın çıkması ve savaşın mali yükünün bütçeyi temelden sarsması neticesinde 1854 yllında Osmanlı Devleti, İngiltere'den 3.300.000 Osmanlı Lirası tutarında \%6 faizli ve 33 yıl vadeli borç almıştır. Osmanlı Devleti, bu ilk borçlanmadan 1875 yllına kadarki süreçte 15 kez daha diş borç alma yoluna gitmiştir $^{3}$. 1 Ekim 1878'de Sadrazam Tunuslu Hayreddin Paşa'nın reisliğinde devletin gerçek gelirlerini tespit ederek bütçe hazırlamak ve bir düzen içine borçların ödenmesini sağlamak amacıyla bir komisyon kurulmuştur ${ }^{38}$. Bab-1 Âli, Osmanlı Bankası ve yerli alacaklılarla 22 Kasım 1879 tarihinde bir mukavele imzalanmış ve ödemelere başlamıştır. Bu anlaşma altı kalem gelire dayandığı için rüsum-u sitte (altı vergi) anlaşması ile anılmıştır. Bu mukavele ile alacaklı olan Osmanlı Bankası ve Galata Bankerlerinin kurduğu "Rüsum-ı Sitte" idaresine, müskirat, pul, İstanbul icarı ve deniz ürünleri rüsumu, İstanbul, Edirne, Bursa ipek öşürü, tömbeki ve tütün inhisarını içeren altı gelir kalemi tahsis edilmiştiræ${ }^{9}$.

TNA., F.O. 195/1450, No. 21 / 1, Harry Charles Augustus Eyres'den G.H. Wyndham'a, 12 Temmuz 1883, ss. 104-105

36 Ahmet Tekin, "Osmanlı Devleti Dış Borçlanması”, Yeni Türkiye, S. 32, Mart-Nisan 2000, ss. 252253.

37 Seyfettin Gürsel, "Osmanlı Dış Borçları", Tanzimat'tan Cumhuriyete Türkiye Ansiklopedisi, Ed. Murat Belge, c. III, İletişim Yayınları, İstanbul 1985, ss. 679- 680.

38 Cevdet Küçük, Tevfik Ertüzün, "Düyun-1 Umumiyye”, Diyanet Vakfi İslam Ansiklopedisi, c. X, Diyanet Vakfi İslam Ansiklopedisi Yayınları, İstanbul 1994, s. 59.

39 Rifat Önsoy, "Muharrem Kararnamesi ve Düyûn-u Umumiye İdaresi”, Osmanlı/İktisat, c. III, Ed. Güler Eren, Yeni Türkiye Yayınları, Ankara 1999, ss. 401-404. 
Tablo 13: Galata Bankerlerinin Erzurum Vilayeti'nden elde ettikleri gelir

\begin{tabular}{|l|l|l|l|l|l|}
\hline \multirow{2}{*}{ Yıl } & Damga Resmi & Müskirat & Tuz & Tütün & Toplam \\
\cline { 2 - 6 } & Kuruş & Kuruş & Kuruş & Kuruş & Kuruş \\
\hline 1880 & 437.761 & 60.098 & 1.732 .050 & 1.166 .134 & 3.396 .045 \\
\hline 1881 & 433.822 & 92.791 & 2.007 .247 & 750.576 & 3.284 .437 \\
\hline 1882 & 557.049 & 110.434 & 1.454 .653 & 586.458 & $2.708 .600^{40}$ \\
\hline 1883 & 494.569 & 105.111 & 2.022 .591 & 449,162 & $3.071 .433^{41}$ \\
\hline
\end{tabular}

1882 yll tuz ${ }^{42}$ ve tütün gelirinde bir hayli azalma olduğu görülmüştür. Bu azalma ise mevcut yönetimdeki bozukluk ve yapılan kaçakçılıktan kaynaklanmıştır. Tütün ticaretinde kaçakçılığın devam ettiğini belirten Konsolos Eyres, kaçakçılığı engellemenin çok zor olduğunu, bekçilerin rüşvet almaya uygun olduklarını, yeni tedbirler kabul edilmezse, gelirlerinin her yıl daha fazla azalma göstereceğini belirtmiştir ${ }^{33}$.

Tablo 14: Galata Bankerlerinin vilayetten elde ettikleri toplam gelir ve çalışanların maaşları ${ }^{4+}$

\begin{tabular}{|l|l|l|l|}
\hline Yll & Toplam Gelir (Kuruş) & Maaşlar (Kuruş) & Net Gelir (Kuruş) \\
\hline 1880 & 3.396 .045 & 1.031 .700 & 2.364 .345 \\
\hline 1881 & 3.284 .437 & 917.873 & 2.366 .564 \\
\hline 1882 & 2.708 .600 & 886.749 & 1.821 .851 \\
\hline 1883 & 3.071 .433 & 793.813 & 2.277 .620 \\
\hline
\end{tabular}

Tütündeki yıllık düşüşle doğru orantılı olarak maaşlarda da düşüş olduğu görülmüştür. 1882 yılında Konsolos Eyres’in bahsettiği tütün kaçakçllı̆ğna

40 TNA., F.O. 195/1450, No. 21/1, Harry Charles Augustus Eyres'den G.H. Wyndham'a, 12 Temmuz 1883, s. 119.

41 TNA., F.O. 195/1481, No.1, William Everett'den Dufferin'e, 10 Haziran 1884, s. 243.

42 Erzurum Tuzlaları ile ilgili ayrıntılı bilgi için bkz; Neşe Erim, "18. Yüzyılda Erzurum Tuzlaları: Osmanlı Tüketim Malları Tarihine Bir Katkı", A.Ü. Türkiyat Araştrmalan Enstitiusï Dergisi, S. 21, Erzurum 2003, ss. 219- 229.

43 TNA., F.O. 195/1450, No. 21/1, Harry Charles Augustus Eyres'den G.H. Wyndham'a, 12 Temmuz 1883, ss. 99-120.

44 TNA., F.O. 195/1481, No.1, William Everett'den Dufferin'e, 10 Haziran 1884, s. 243. 
Konsolos Everett’te değinmiş tütün kaçakçılığın arttığını, çalışanların da kaçakçılığı önleyebilmek için yeterli güce sahip olmadıklarını belirtmiştir ${ }^{45}$.

Osmanlı Devleti’nin tütünden aldığı vergiler, Muharrem Kararnamesi ile Düyûn-1 Umûmiyye İdaresi’ne bırakılmışt1 ${ }^{46}$. Düyûn-1 Umûmiyye İdaresi ise, tütünden alacağı vergileri Alman ve Avusturya Bankerleri ile Osmanlı Bankası Sermayesi ortaklığıyla kurulmuş Reji İdaresi'ne bırakmıştır. Bu anonim şirket, Düyun-1 Umumiye İdaresi ve Osmanlı Devleti yöneticileri tarafindan onaylanan 1883 tarihli şartname ile çalışmalarına başlamıştır ${ }^{4}$ Konsolos Everett, Erzurum Vilayeti tütün gelirlerinin rejinin eline geçtiğini ve aktif olarak çalıştıklarını belirtmiştir ${ }^{48}$.

TNA., F.O. 195/1481, No.1, William Everett'den Dufferin'e, 10 Haziran 1884, s. 223-245. Düyun-ı Umûmiyye İdaresi bünyesinde çalışanların çoğunluğunu Osmanlı tebaası oluşturmaktaydı. Alt kademede Müslüman nüfusun istihdam edilmesinin temel nedeni ise vergilerin toplanmasında yabancıların kullanılmasının tehlikeli görülmesidir. Bkz; Donald Quataert, "Düyun-1 Umumiye'nin İstihdam Politikaları (1881-1909)", çev. Ahmet Fethi, Toplumsal Tarih, sy.79, Temmuz 2000, ss. 15-16.

46 Erdoğan Keskinkılıç, "Bir Osmanlı Özelleştirme Modeli: Reji-Tütün İdaresi”, Liberal Diüsünce, Bahar 1999, s. 151. Avrupalı alacaklılar ile Osmanlı Devleti arasındaki görüşmeler neticesinde 20 Aralık 1881'de 21 maddeden oluşan Muharrem Kararnamesi imzalanmıştır. Muharrem Kararnamesi sonucunda Düyûn-ı Umûmiyye kurularak, devletin gelir kaynakları denetlenmeye başlanmıştır. Muharrem Kararnamesinin 15. maddesi gereğince, temsilci olarak tahvil sahiplerinin ve onların menfaatlerini korumak amacıyla Düyûn-ı Umûmiyye Meclisi kurulmuştur. Resmi ismi "Düyûn-ı Umûmiyye-i Osmaniye-i Meclis-i İdaresi" olan kuruluş "Düyûn-ı Umûmiyye İdaresi" olarak anılmıştır. Bu kuruluşun, ikametgâhı İstanbul olan yedi asli üyeden oluşan bir konsey teşkil etmesi kararlaştırılmıştır. Bu konseyin üyelerinden beşi Avrupalı tahvil sahibi temsilcisi, biri Osmanlı tahvil sahibi temsilcisi, biri de iç borçlar temsilcisi statüsünde olması kararlaştırılmıştır. Devletin bazı bölgelerinde uygulanan "Tuz İnhisarı Gelirleri”, "Damga Resmi", "Müskirat Rüsumu", "Balık Rüsumu”, "İpek Öşürü Geliri”, "Tütün Öşürü ve Tütün Rejisi”, "Bulgaristan Vergisi", "Kıbrıs Adası Gelir Fazlası", "Şarkî Rumeli Geliri”, "Tömbeki Geliri”, "Sırbistan, Karadağ ve Yunanistan’ı Payları", "Gümrük Hasılatı Fazlası”, "Şarki Rumeli Geliri”, "Patent Vergisi Geliri Fazlası", "Hasılat Fazlası Gelirleri” Düyûn-ı Umûmiyye İdaresine devredilmiştir. Bkz; Küçük, Ertüzün, a.g.m., s. 59; Bernard Lewis, Modern Türkivenin Doğuşu, Türk Tarih Kurumu Yayınları, Ankara 1998, s. 447; Sait Açba, Osmanl Devletinin Dış Borçlanması (1854-1914), Akü Yayınları, Afyon 1995, s. 97; Erdoğan Keskinkılıç, "Düyun-ı Umumiye İdaresi", Türkler, c. XIV, Yeni Türkiye Yayınları, Ankara 2002, ss. 374-375; Haydar Kazgan, "Düyun-1 Umumiye", Tanzimat'tan Cumhuriyet'e Türkiye Ansiklopedisi, Ed. Murat Belge, c. III, Iletişim Yayınları, İstanbul 1995, ss. 709-713. 


\section{4. İthalat-İhracat}

\section{a. Ithalat}

93 Harbi sonrası bölgede yaşanan sükûnetle birlikte transit ticaret gelirlerine önemli ölçüde iyileşme görülmüştür. İran, dönem itibariyle pahalı emtianın büyük bir kısmının ticaretini Erzurum üzerinden yapmıştır. Özellikle 1882 yılında, 18801881 yll toplam ithalatının \%50'sinden daha fazla ithalat yapıldığı görülmektedir.

Tablo 15: 1882 yılı İran'dan ithal edilen ürünler

\begin{tabular}{|l|l|l|}
\hline Ürün & Balya & Değer $(£)$ \\
\hline Mazı & 400 & 1.600 \\
\hline Halı & 3.481 & 139.240 \\
\hline Şal & 420 & 63.000 \\
\hline Deri & 450 & 3.170 \\
\hline İpek & 372 & 37.200 \\
\hline Tömbeki & 12.870 & 104.250 \\
\hline Yün & 132 & 672 \\
\hline Misina & 194 & 1.358 \\
\hline $\begin{array}{l}\text { Ufak tefek } \\
\text { eşyalar }\end{array}$ & 976 & 3.904 \\
\hline Toplam & 19.295 & 354.394 \\
\hline
\end{tabular}

Tablo 16: İran'dan alınan emtianın 1880, 1881 ve 1882 yıllarına ait karşılaştırmalı istatistiği

\begin{tabular}{|l|l|l|}
\hline Yil & Balya & Değer $(£)$ \\
\hline 1880 & 10.605 & 169.234 \\
\hline 1881 & 12.690 & 217.340 \\
\hline 1882 & 19.295 & 354.394 \\
\hline Toplam & 42.590 & 740.968 \\
\hline
\end{tabular}

Konsolos Eyres, ticaretteki bu büyümenin Erzurum'dan Tebriz'e giden yolun güvenli olmasından kaynaklandığını ancak Trabzon ve Tiflis güzergâhında deve kiralamanın daha ucuz olduğu için ticarette dalgalanmalar yaşandığınıyaşanacă̆ını belirtmiştiri๋.

49 TNA., F.O. 195/1450, No. 21/1, Harry Charles Augustus Eyres'den G.H. Wyndham'a, 12 Temmuz 1883, ss. 99-120. 
Tablo 17: 1883 yllında İran ve Rusya'dan ithal edilen ürünlerin miktar ve değerleri ${ }^{50}$

\begin{tabular}{|c|c|c|}
\hline Ülke & Miktar & Değer $(£)$ \\
\hline İran & 19.308 & 105.160 \\
\hline İran & 351 d (Tömbeki) & 880 \\
\hline Rusya & $2.793 \mathrm{~d}$ & 29.530 \\
\hline Toplam & & 135.570 \\
\hline
\end{tabular}

Rusya'dan keten, sığır derisi, kuzu yünü, pelerin, kıyafet, gümüş tel, ipek ve küçük bir miktar baskılı patiska ithal edilmiştir. İan’dan şal, ipek iplik, kına, tömbeki, zırnık, halı, pirinç, kurutulmuş meyve, pamuk ve yün ithal edilmiştir ${ }^{5 ı}$. 1883 yılında İran'dan ithal edilen emtiayı bir önceki yılla karşılaştırdığımızda üçte bir oranında düşüş olduğu görülmektedir. Rusya'dan ithal edilen emtianın değerinde ise 1883 yılında az da olsa artış görülmüştür ${ }^{52}$.

Tablo 18: 1882 yılı İngiltere'den ithal edilen ürünlerin miktar ve değerleris3

\begin{tabular}{|l|l|l|}
\hline Ürün & Miktar & Değer $(£)$ \\
\hline Çay $($ Okka) & 3.335 & 1.000 \\
\hline Biber (Okka) & 2.000 & 200 \\
\hline Demir (Okka) & 967.590 & 20.600 \\
\hline Bakır (Okka) & 42.000 & 6.000 \\
\hline Kurşun kalay alaşımı (nesne) & - & 1.000 \\
\hline Şap & - & 500 \\
\hline Kırmız (Okka) & 187 & 500 \\
\hline Çivit (Okka) & 1.000 & 1.000 \\
\hline Dikiş ipliği & - & 2.000 \\
\hline Pamuk ipliği (lbs) & 30.000 & 3.000 \\
\hline Patiska (Parça) & 967.590 & 30.600 \\
\hline Yatak örtüsü (parça) & 1.125 & 1.137 \\
\hline
\end{tabular}

50 TNA., F.O. 195/1481, No.1, William Everett'den Dufferin'e, 10 Haziran 1884, ss. 223-245.

51 TNA., F.O. 195/1450, No. 21/1, Harry Charles Augustus Eyres'den G.H. Wyndham'a, 12 Temmuz 1883, ss. 99-120. TNA., F.O. 195/1481, No.1, William Everett'den Dufferin'e, 10 Haziran 1884, ss. 223-245.

53 TNA., F.O. 195/1450, No. 21/1, Harry Charles Augustus Eyres'den G.H. Wyndham'a, 12 Temmuz 1883, s. 106. 


\begin{tabular}{|l|l|l|}
\hline Kökboyası (Pamuk) (Parça) & 500 & 100 \\
\hline Pazen (Parça) & 500 & 1.000 \\
\hline Tülbent (Parça) & 10.000 & 1.800 \\
\hline Kaba pamuklu kumaş (Parça) & 200 & 200 \\
\hline Toplam & & 70.437 \\
\hline
\end{tabular}

Tablo 19: 1882 yılı diğer ülkelerden ithal edilen ürünlerin miktar ve değerleri ${ }^{5+}$

\begin{tabular}{|c|c|c|c|}
\hline Ülke & Ürün & Miktar & Değer $(£)$ \\
\hline \multirow[t]{11}{*}{ Fransa } & Kıyafet (Parça) & - & 3.000 \\
\hline & Halı (Parça) & - & 95 \\
\hline & Çivi (F1çı) & 1.834 & 2.000 \\
\hline & Şeker (Okka) & 1.297 .260 & 8.000 \\
\hline & Kahve & 24.000 & 2.000 \\
\hline & Çarşaf (Okka) & 250 & 50 \\
\hline & Deri (Okka) & 71.428 & 25.000 \\
\hline & Çelik & - & 400 \\
\hline & Mum (Kilo) & 20.000 & 1.500 \\
\hline & Hirdavat & - & 500 \\
\hline & Alkol & - & 600 \\
\hline \multirow[t]{8}{*}{ Avusturya } & Tirpan & 60 & 300 \\
\hline & Sigara Kâğgdı & - & 3.000 \\
\hline & Kiyafet & - & \\
\hline & Fes & 36.000 & 2.500 \\
\hline & $\begin{array}{l}\text { Cam eşya ve } \\
\text { çanak çömlek }\end{array}$ & - & 1.000 \\
\hline & Yazı kâğıdı & - & 1.000 \\
\hline & Ufak tefek eşyalar & - & 12.000 \\
\hline & Kalay & - & 150 \\
\hline
\end{tabular}

54 TNA., F.O. 195/1450, No. 21/1, Harry Charles Augustus Eyres'den G.H. Wyndham'a, 12 Temmuz 1883, ss. 106-107. 


\begin{tabular}{|l|l|l|l|}
\hline \multirow{4}{*}{ Amerika } & Petrol (Kutu) & 30.000 & 18.000 \\
\cline { 2 - 4 } & Alkol & - & 2.200 \\
\cline { 2 - 4 } & Ufak tefek eşyalar & - & 1.000 \\
\cline { 2 - 4 } & & & 21.200 \\
\hline Almanya & Bardak & & 800 \\
\hline İtalya & Kibrit (Kutu) & 1.600 & 4.000 \\
\hline İsviçre & Tülbent \& Fular & & 10.000 \\
\hline
\end{tabular}

İngiltere'den ithal edilen ürünler, diğer tüm ülkelerden ithal edilen emtianın yaklaşı beşte ikisini oluşturmaktadır. Bu ürünler arasında da Manchester emtiası, yaklaşık $40.000 £$ değeriyle en önemli kalemdir. İngiliz ürünleri ile diğer ülkelerin pazar değerini karşılaştırdığımızda İngiltere'nin ön planda olduğu açıça görülmektedir. Bazı emtiada Rusya, İngiliz emtiasıyla az da olsa rekabet edebilmiştir. 1863 yllında önemli miktarda pamuklu eşya Almanya'dan ithal edilirken İngiliz emtiasının kalitesi ve nispeten ucuzluğu nedeniyle Alman ürünleri piyasadan çekilmiştir.

Erzurum Konsolosu Sir Robert Dalyell'in ${ }^{55} 1863$ yllında verdiği istatistiklerle 1880 yılları karşılaştırıldığında Avrupa'dan ithal edilen ürünlerin toplam değerinin birbirine yakın olduğu, ancak toplamda İngilizlerin piyasadaki payının öncekine kıyasla önemli oranda büyüdüğü görülmektedir. Diğer ülkeler ile kıyaslandığında 1882 yllında İngiltere'nin Erzurum piyasasındaki geliri 70.000£ iken diğer tüm ülkelerin geliri $135.000 £$ değerindedir. Savaş sonrası Erzurum halkının ekonomik sıkıntılar nedeniyle zorunlu tüketim mallarına yöneldikleri, buna bağlı olarak pamuklu ürünlere olan talebin azaldığ̣ görülmektedir. 20 yıl içinde (1863-1883) Erzurum piyasasında en büyük büyümeyi Fransa kaydetmiştir, Fransa'dan yapılan ithalat 5 misline çıkmıştır. Fransa'dan ithal edilen ürünlerde ana artış kıyafet, deri ve şekerde olmuştur. 1863 yllında kıyafet ve derinin değeri sadece $650 £$ iken yaklaşık 20 yıl içinde $27.350 £ ' e$ ulaşmıştır. Şekerin değeri 5.700 £'den $8.000 £ ' e$

Sir Robert Alexander Osborne Dalyell, 6 Şubat 1859'da Erzurum Konsolosluğu'na atanmıştır. 1860 yılında birkaç ay büyükelçilikte çalışmış ve 1860 yllının Temmuz ayında Selanik'teki olaylar münasebetiyle özel görevle Selanik'e gönderilmiştir. 1860 yllını sonbaharında Erzurum’a geri dönmüştür. Kaynak olarak kullandığımız kitapta Dalyell'in "Ermenistan ve Kürdistan" olarak belirtilen bölgenin büyük bölümünü gezdiği belirtilmiştir. 8 Aralık 1862'de Moldovya'ya transfer olmuştur. Bkz; The Foreign Office List: Forming a Complete Diplomatic and Consular Handbook for 1870, Compiled by Edward Hertslet, C.B., Thirty-sixth Publication, London, pp. 81-82. 
yükselmiştir. Bu süre içinde Almanya ile yapılan ticaret hemen hemen sıfira inmiştir ${ }^{56}$.

Tablo 20: 1883 yılı Avrupa'dan ithal edilen ürünler ${ }^{57}$

\begin{tabular}{|l|l|l|l|l|}
\hline Ülke & Ürün & Miktarı & $\begin{array}{l}\text { Değeri } \\
\text { (Sterlin) }\end{array}$ & Toplam \\
\hline İngiltere & Çay & 5.000 okka & 1.190 & \\
\hline İngiltere & Biber & --- & 130 & \\
\hline İngiltere & Demir & 350.000 okka & 7.150 & \\
\hline İngiltere & Bakır & 20.000 okka & 2.720 & \\
\hline İngiltere & Kurşun ve kalay alaşımı (nesne) & 100 balya & 910 & \\
\hline İngiltere & Şap & --- & --- & \\
\hline İngiltere & Kökboyası & --- & 140 & \\
\hline İngiltere & Çivit & --- & 450 & \\
\hline İngiltere & Amerikan bezi-patiska & 860.830 parça & 27.540 & \\
\hline İngiltere & Yastık-minder kıllfi & 1.013 parça & 1.030 & \\
\hline İngiltere & Türk kırmızı/kök kırmızıs1 & --- & 90 & \\
\hline İngiltere & Pazen & --- & 900 & \\
\hline İngiltere & Kumaş & --- & 1.620 & \\
\hline İngiltere & Kaba pamuklu kumaş & --- & 180 & 44.050 \\
\hline Fransa & Kahve & 2.000 balya & 6.540 & \\
\hline Fransa & Mum & 10.000 kilogram & 4.530 & \\
\hline Fransa & Hırdavat & --- & 910 & \\
\hline Fransa & Şeker & 5.000 balya & 15.000 & \\
\hline Fransa & ----- & 500 kuruş & 2.050 & \\
\hline Fransa & Etonol-Alkol & --- & 490 & \\
\hline Fransa & Mih & 500 fiçı & 660 & \\
\hline Fransa & Ģinko & 15 balya & 60 & \\
\hline Fransa & Deri & 150 kutu & 250 & 48.670 \\
\hline Fransa & Gelik & 4.500 balya & 18.180 & \\
\hline Avusturya & Şeker & & \\
\hline
\end{tabular}

56 TNA., F.O. 195/1450, No. 21/1, Harry Charles Augustus Eyres'den G.H. Wyndham'a, 12 Temmuz 1883, ss. 99-120.

57 TNA., F.O. 195/1481, No.1, William Everett'den Dufferin'e, 10 Haziran 1884, ss. 227-229. 


\begin{tabular}{|l|l|l|l|l|}
\hline Avusturya & Tirpan & 7.000 & 320 & \\
\hline Avusturya & Sigara kâğıdı & 1.000 kutu & 8.520 & \\
\hline Avusturya & Kıyafet & 3.500 parça & 14.320 & \\
\hline Avusturya & Fes & 36.000 & 1.800 & \\
\hline Avusturya & Cam eşya, çanak çömlek & --- & 460 & \\
\hline Avusturya & Yazı kâğıdı & --- & 910 & \\
\hline Avusturya & Kalay & --- & 550 & \\
\hline Avusturya & Çinko & --- & 60 & \\
\hline Avusturya & Çeşitli ufak tefek eşyalar & --- & 10.000 & 41.440 \\
\hline Amerika & Petrol & 10.000 kutu & 5.910 & \\
\hline Amerika & Etanol-Alkol & 14.000 okka & 1.080 & \\
\hline Amerika & Çeşitli ufak tefek eşyalar & --- & 730 & 7.720 \\
\hline Almanya & Pencere camı & --- & 590 & 590 \\
\hline İtalya & Kibrit & 1.500 kutu & 4.290 & 4.290 \\
\hline İsviçre & Mendil & --- & 8.000 & 8.000 \\
\hline Toplam & & & & 154.760 \\
\hline
\end{tabular}

1883 ylında Avrupa'dan ithal edilen emtiada \%14.6’lık düşüş yaşanmış, en büyük düşüş İngiltere'den alınan ürünlerde görülmüsstür. 1882 yllında ithal edilen emtianın değeri $70.437 £$ iken 1883 yll sadece $44.050 £$ değerindedir ve Amerika'dan yapılan ithalat $21.200 £$ iken $7.720 £$ gerilemiştir. Amerikan ticaretini etkileyen ana etmen ise Bakü'den Batum'a giden demiryolunun tamamlanması ve ucuz Rus petrolünün daha çok ithal edilmesidir. 1883 yılı çerçevesinde sadece Avusturya ve İtalya'nın ticaret hacmi artmıştır. İngiliz tüccarlardan alınan demir ve bakır miktarı \%60 düşmüştür. Sadece patiskaların olağan arzı karşılamak için yeterli olduğu görülmüştür. Deri ithalatı $\% 27$ oranında düşmüştür, halı ithalatı ise hemen hemen durma noktasına gelmiştir. Öte yandan kahve, çinko ve hırdavat ürünlerinin 1882 yılı ile karşılaştırıldığında ithalat değerinin arttığı görülmektedir. Şebinkarahisar'dan gönderilen-yönlendirilen az miktarda şap listeden çıkartılmıştır ve çay hariç diğer emtiada \%10’luk bir düşüs yaşanmıştır.

1883 yllinda Fransa'dan ithal edilen emtia, İngiltere'den ithal edilen emtiayı değer olarak geçmiştir, ancak önceki yıllar ile karşılaştırıldığında Fransız emtiasının ithalinde düşüş olmuş, en temel düşüş şeker de yaşanmıştır. Konsolos Everett, bu azalışı Brumn'daki Avusturya şirketinin şeker ticareti yapmasına bağlamıştır. 
Avusturya'dan alınan fes, cam eşya, çanak-çömlek, kırtasiye ve çeşitli ufak tefek eşyaların ithalatında düşüş yaşanmasına rağmen, şeker, sigara kâğıdı, kıyafet, diğer yeni ürünlerle beraber $4.500 £$ değerindeki ticaret hacmi $41.440 £$ 'e ulaşmıştır.

Almanya'dan alınan ürünlerin değer ve miktarlarını ithalat yapan diğger ülkeler ile kıyasladığımızda Alman ürünlerinin Erzurum pazarında önemli ticarî bir değere sahip olmadığı görülmektedir. Almanya'dan sadece pencere camı alınmış, bu ürünün değeri de $800 £^{\prime} d e n$ 590£'e düşmüştür.

1883 yılında İsviçre'den alınan kumaşın değerinde 2.000£’lik bir düşüş olmuştur. Bu düşüş ise halkın daha çok Erzincan ve Tokat'ta baskı yapılan Manchester kumaşını tercih etmesinden kaynaklanmıştır.

1883 yllında Avrupa'dan 154.760£, İran ve Rusya'dan 135.570£ değerinde ürün alınmıştır ${ }^{58}$.

Tablo 21: 1884 ve 1885 yıllarında Erzurum Vilayeti'ne yapilan ithalat ${ }^{59}$

\begin{tabular}{|l|l|l|}
\hline \multirow{2}{*}{ Ülke } & \multicolumn{2}{|c|}{ Ithalat (£) } \\
\cline { 2 - 3 } & 1884 & 1885 \\
\hline İngiltere & 48.910 & 54.820 \\
\hline Fransa & 50.930 & 41.020 \\
\hline Avusturya & 48.180 & 43.910 \\
\hline Rusya & 45.430 & 43.530 \\
\hline İsviçre & 9.600 & 8.700 \\
\hline İran & 71.000 & 59.000 \\
\hline Diğger Ülkeler & 3.020 & 2.380 \\
\hline Toplam & 339.570 & 305.410 \\
\hline
\end{tabular}

Konsolos Devey, Osmanlı Devleti’nin diğger vilayetlerinden alınan ürünlerin değerlerine de yer verilmiştir. Erzurum Vilayeti’ne 1884 yılında 62.500£, 1885 yılında $52.050 £$ değerinde ürün diğer vilayetlerden alınmıştır. 
Tablo 22: 1884 ve 1885 yllarında Erzurum Vilayeti'ne ithal edilen temel ürünlerin miktar ve değerleri

\begin{tabular}{|l|l|l|l|l|}
\hline \multirow{2}{*}{ Ürün } & \multicolumn{2}{|l|}{1885} & \multicolumn{2}{l|}{1884} \\
\cline { 2 - 5 } & Miktar & Değer $(£)$ & Miktar & Değer $(£)$ \\
\hline Şeker & 9.000 Balya & 25.630 & 8.000 Balya & 18.380 \\
\hline Kahve & 3.500 Balya & 15.270 & 3.000 Balya & 11.800 \\
\hline & $11.000 \mathrm{Cwt}$ & 9.500 & $10.000 \mathrm{Cwt}$ & 9.000 \\
\hline Bakır & $550 \mathrm{Cwt}$ & 2.900 & $900 \mathrm{Cwt}$ & 4.100 \\
\hline Deri & & 12.000 & & 10.000 \\
\hline Manchester emtiası & & 29.940 & & 32.920 \\
\hline Yazma ve mendil & & 11.270 & & 11.000 \\
\hline Yünlü eşyalar & & 32.830 & & 32.850 \\
\hline Hayvan postu & 11.200 & 17.600 & 10.000 & 13.150 \\
\hline Diğger ürünler & & 49.130 & & 51.160 \\
\hline Toplam & & 206.070 & & 194.360 \\
\hline İran'dan alınan emtia & & 71.000 & & 59.000 \\
\hline Toplam & & 277.070 & & 253.360 \\
\hline
\end{tabular}

Tablo 23: 1884-1885 yılları diğer vilayetlerden ithal edilen temel ürünlerin miktar ve değerleri

\begin{tabular}{|l|l|l|l|l|}
\hline \multirow{2}{*}{ Ürün } & \multicolumn{2}{|l|}{} & 1885 \\
\cline { 2 - 5 } & Miktar & Değer $(£)$ & Miktar & Değer $(£)$ \\
\hline Manusa $^{60}$ & $\begin{array}{l}118.000 \\
\text { Parça }\end{array}$ & 11.860 & $\begin{array}{l}214.000 \\
\text { Parça }\end{array}$ & 20.730 \\
\hline Kürk-Furs & & 8.020 & & 5.400 \\
\hline
\end{tabular}

60 Manusa ve ya "Arapkir Alacası" denilen pamuklu (çok az bir kısmı da ipekli) kumaş dokumalar, Anadolu'ya ve Anadolu dışındaki bazı yerlere pazarlanmıştır. Dokuma çeşitleri bakımından jakarlı dokumalar, ipekli dokumalar, baskı yapılan düz dokumalar olmak üzere üç gurupta toplanan "Arapkir Manusası"; yastık yüzü, yorgan yüzü, çarşaf, sofra bezi, perdelik, desenli gömleklikler, şalvarlık, entarilik olarak kullanılmıştır. El tezgâhlarında üretilen manusa kumaşı ise dönemin en pahalı kumaşı ve ticaret ürünlerinden biridir. Bkz; Ahmet Yakman, 163 Nolu Arapkir Şerìye Siciline Göre Arapkir, Yüksek Lisans Tezi, İnönü Üniversitesi Sosyal Bilimler Enstitüsü, Malatya 2015, s. 48. 


\begin{tabular}{|l|l|l|l|l|}
\hline Tiftik & 882 Balya & 5.290 & --- & \\
\hline---- & 2.150 Cwt & 3.610 & 1.245 Cwt & 2.280 \\
\hline Keçi ve Koyun Derisi & 42.000 & 3.870 & 15.000 & 1.060 \\
\hline Diğer ürünler & & 29.850 & & 22.580 \\
\hline Toplam & 134.130 & Toplam & 111.050 \\
\hline
\end{tabular}

İthalatı yapılan başlıca ürünler şeker, kahve, yünlü ürünler, bakır, manusa, tiftik ve bazı diğger ürünlerdir. 1884-1885 yıllarında Erzurum Vilayeti’ne ithal edilen Avrupa ürünlerinin fiyatlarında genel olarak azalma olmuştur.

Şeker: 1884 yllında olduğu gibi 1885 yılında da 6.000 balya şeker Fransa'dan ithal edilmiştir. Her balyası yaklaşık 1 1/2 cwt $^{61}$ ağırlığında olan şekerin balya fiyatı 58 şilinden yaklaşı 47 şiline $(47 \mathrm{~s} / 6 \mathrm{~d})$ düşmüştür. Avusturya şekerinden 1.000 balya alınmıştır, balya fiyatı 42 şiline düşmüştür.

Kahve: Kahve alımında azalma olmuştur. Kahve fiyatında da Fransa'dan elde edilen kahvenin kaliteli olmamasından dolayı $1 £ 2$ şilin değerinde azalma olmuştur.

Yünlü Eşyalar: Rusya ve Avusturya pazarından yaklaşık 30.000 sterlin değerinde yünlü eşya satın alınmıştır. Avusturya'dan alınan kıyafetlerin fiyatlarında yükselme olmuştur. 1885 yılında ihraç edilen ürünler arasından fiyatı yükselen tek ürün Avusturya'dan alınan kıyafetlerdir. Rusya'dan alınan ürünlerin fiyatı ise her parçası 20 şilinden 18 şiline düşmüştür. İngiliz pazeni de Rus rekabeti nedeniyle $730 £^{\prime}$ den 500£'ne düşmüştür.

Bakır: Bakır alımında artış olmuş fiyatında ise cwt başına yaklaşık $1 £$ düşüş olmuştur. Fiyatında düşmenin devam ettiği bakır için İstanbul'daki tüccarlar yaklaşık 63 şilin (63s/6d) teklif etmişlerdir.

Kibrit: Kibrit, önceden İtalya'dan alınırken sonraki dönemlerde Avusturya'dan alınmaya başlanmıştır. Alım 1.300 kutudan 2.000 kutuya yükselmiş, fiyatlar \%16 oranında düşmüştür.

61 Cwt, İngiltere'de 50.8, Amerika'da 45.35 kilograma denk gelen ağırlık ölçü birimidir. Bundan hareketle her balyanın yaklaşık 25 kilograma denk geldiği anlaşılmaktadır. Bkz;https:// dictionary.cambridge.org/tr $/ \mathrm{s} \% \mathrm{C} 3 \% \mathrm{~B} 6 \mathrm{zl} \% \mathrm{C} 3 \% \mathrm{BCk} /$ ingilizce-t $\% \mathrm{C} 3 \% \mathrm{BCrk} \% \mathrm{C} 3 \% \mathrm{~A} 7 \mathrm{e} / \mathrm{cwt}$ (11.12.2018). 
Petrol: Daha önceki dönemlerde petrol Amerika'dan ithal edilirken, 1884 yllında artık petrolün Amerika'dan ithal edilmediğini görmekteyiz. 1884'de 5.550 $£$ değerinde petrol, Rusya'dan ithal edilmiştir.

Çay: Rusya'dan ithal edilen çayın değeri 1884'de 1.190£ iken 1885'de halkın çayı veresiye alabilmesi nedeniyle alım 3.700£'e çıkmıştır.

Şilte: Şilte, Rusya ve Manchester'dan alınmıştır. Ancak halk tarafindan daha çok Manchester şiltesi tercih edildiği için Rus ürünleri, İngiliz ürünleri ile rekabet edememiştir.

İran'dan alınan emtia: İran'dan alınan temel ürünler $27.000 £$ değerinde ipek ve şal, ihracat için $8.000 £$ değerinde koyun, 5.000£ değerinde halıdır. Bunların dışında İran’dan alınan diğger mallar; nargile tütünü, pirinç, kurutulmuş meyve, kilim (Kürt ince kilim), jejim (daha çok at kıyafetleri için kullanılan yünlü ürün), ham pamuk, yün, hayvan postu, deri, kına, sarı zırnık, az sayıda at, katır ve eşektir. 1885 yılında Erzurum piyasasındaki para azlığı nedeniyle İan'la yapılan ticarette yaklaşık \%20 oranında bir azalma olmuştur ${ }^{62}$.

\section{b. İhracat}

Harp ve harp sonrası ihracatta yaşanan durgunluk özellikle 1882 yılında son bulmuştur. İhracat tekrar hareketlenmiş ve ihracatta \%65'lik bir büyüme yaşanmıştır. Kıyafet, yünlü ürünler ve ipek ihracatında önemli oranda artış olmuştur. Özellikle 93 Harbi sonrası iş imkânlarının azalması, ticaretin durma noktasına gelmesinin ardından ihracattaki bu artış halkın refahı için son derece önemli bir gelişme olmuştur. Konsolos Eyres, 93 Harbi sonrasında işçi sınıfının fakirliğinin aşırı vergiler nedeniyle değil ticaretin azalmasından kaynaklandığını belirtmiştir ${ }^{63}$.

Erzurum'dan ihracat yapılan başlıca ülkeler İran, Rusya, İngiltere, Fransa ve Avurturya'dır. Rusya'ya ihraç edilen başlıca ürünler; kürk, deri ve keten (Rize'de imal edilmiş), mazı (Bitlis'den), pamuklu emtia (Manchester pamuğundan Diyarbakır'da imal edilmiş), ipek ve sabundur (Halep’ten). Ürünler Erzurum vasıtasıyla Rusya’ya ihraç edilmiştir. Bizzat Erzurum Vilayeti’nden tedarik edilip

TNA, F.O. 195/1552, No. 6/1, George Pollard Devey'den Sir E. Thornton'a, 16 Temmuz 1886 , ss. 90-99.

63 TNA., F.O. 195/1450, No. 21/1, Harry Charles Augustus Eyres'den G.H. Wyndham'a, 12 Temmuz 1883, ss. 99-120. 
Osmanlı coğrafyasının diğer bölgelerine ya da diğer ülkelere yapılan ihracat çok fazla bir öneme sahip değildir. Konsolos Eyres, ticaretteki gümrük vergisinin Erzurum'dan alınmadığı, kaldırıldığı ve emtianın hesabının tutulmadığı için miktarı doğru tahmin etmenin pek mümkün olmadığını belirtmiştir. Erzurum'da üretilen, imal edilen ve başlıca satışı yapılan ürünler; kürk, deri, mum, tutkal/ yapıştırıcı, sakız, misina, deri ve buğgdaydır.

Tablo 24: 1882 yılı Erzurum Vilayeti'nden ihracatı yapılan ürünler

\begin{tabular}{|l|l|l|}
\hline Ürün & Balya & Değer $(£)$ \\
\hline Kumaş & 1.165 & 90.300 \\
\hline $\begin{array}{l}\text { Pamuk ve yünlü mamul } \\
\text { ürünler }\end{array}$ & 24.269 & 607.268 \\
\hline Çanak çömlek, cam eşya & 3.421 & 6.083 \\
\hline Hirdavat & 474 & 2.370 \\
\hline Kibrit & 1.700 & 3.400 \\
\hline İpek & 172 & 25.800 \\
\hline Ufak tefek eşyalar & 642 & 2.676 \\
\hline Çay & 1.800 & 14.400 \\
\hline Toplam & 33.843 & 752.297 \\
\hline
\end{tabular}

Tablo 25: 1880, 1881, 1882 yılları karşılaştırmalı ihracat istatistiği

\begin{tabular}{|l|l|l|}
\hline Yll & Balya & Değer $(£)$ \\
\hline 1880 & 20.859 & --- \\
\hline 1881 & 20.095 & --- \\
\hline 1882 & 33.843 & 752.297 \\
\hline Toplam & 74.797 & --- \\
\hline
\end{tabular}


Tablo 26: Bir ylllı tahmini ihracat miktar ve rakamlar1 ${ }^{64}$

\begin{tabular}{|l|l|l|}
\hline Ürün & Birim Fiyat & Değer (Sterlin) \\
\hline Çiriş & 5.000 balya & 5.000 \\
\hline Pastırma & 2.000 balya & 8.000 \\
\hline İnek, öküz & 15.000 adet & 34.000 \\
\hline Koyun & 40.000 adet & 25.000 \\
\hline Misina & 50.000 adet & 450 \\
\hline Kürk & 60.000 adet & 15.000 \\
\hline Buğday & 200.000 kile ${ }^{65}$ & 29.700 \\
\hline Deri & 64.000 adet & 16.500 \\
\hline Toplam & 436.000 & 133.650 \\
\hline
\end{tabular}

Çiriş ve pastırma Osmanlı coğrafyasının diğer bölgelerine, buğdayın büyük bir kısmı Trabzon'a az miktarda ise Marsilya'ya ihraç edilmiştirín.

Tablo 27: 1883 yılı Avrupa'ya yapılan ihracat miktar ve değeri

\begin{tabular}{|l|l|l|}
\hline Ürün & Miktar & Değer $(£)$ \\
\hline Çiriş & 500 Balya & 450 \\
\hline Misina & 55.000 & 370 \\
\hline Kürk & --- & 3.830 \\
\hline Deri & 45.000 & 7.270 \\
\hline Buğday & --- & 4.040 \\
\hline Mazı & --- & 2.320 \\
\hline Mum & --- & 2.100 \\
\hline Kitre & --- & 600 \\
\hline
\end{tabular}

64 Bu tablo dâhilindeki ürünler yurt dışına ithal edilmekle birlikte bir kısmı da Osmanlı coğrafyasının diğer bölgelerine satılmıştır.

651 eski kile $=4$ şinik=8 kutu= 37 litre iken 26 Eylül 1869 tarihli ölçü reformu ile 1 kile-i a'şari=10 onluk=100 ölçek=100 litre kabul edilmiştir. Ölçülerin değerinin yeniden belirlendiği 24 Eylül 1881 tarihli kararnâme ile 1 yeni kile $=100$ yeni şinik $=100$ ölçek $=1.000$ yeni kutu 10.000 zarf olmuştur. Bkz; Cengiz Kallek, "Kile", Diyanet Vakf İslam Ansiklopedisi, Cilt: XXV, Türk Diyanet Vakfi Yayınları, İstanbul 2002, s. 570.

66 TNA., F.O 195/1450, No. 21/1, Harry Charles Augustus Eyres'den G.H. Wyndham'a, 12 Temmuz 1883, ss. 99-120. 
1883 yılı Avrupa'ya yapılan ihracat miktarında büyüme olmamış aksine ortalamada bir hayli düşüş olmuştur.

Tablo 28: 1883 yılı İran ve Rusya'ya yapılan ihracat miktar ve değeri

\begin{tabular}{|l|l|l|}
\hline Ülke & Miktar & Dĕ̆er $(£)$ \\
\hline İran & 112 balya & 390 \\
\hline Rusya & $33.982 \mathrm{~d}$. & 14.480 \\
\hline Toplam & & 14.870 \\
\hline
\end{tabular}

1883 yılında İran ve Rusya'ya yapilan ihracat 14.870£, Avrupa'ya yapılan ihracat 20.980£'dir. Türkiye'nin diğer bölgelerine yapılan satış ise $47.710 £$ değerindedir. Erzurum Vilayeti'ne aynı dönem yapılan ithalat 356.160£'dir, ithalat lehine denge 272. $610 £$ değerindedir ${ }^{67} .93$ Harbi öncesi konsolosluğun hazırlamış olduğu 1872 yılı verilerinde Erzurum'dan Avrupa'ya yapılan ihracatın 1883 yılı ile kıyaslandığında 3 katından fazla olduğu görülmektedir ${ }^{68}$.

Tablo 29: 1884 ve 1885 yıllarında yapılan ihracat ${ }^{69}$

\begin{tabular}{|l|l|l|}
\hline \multirow{2}{*}{ Ülke } & İhracat $(£)$ & 1885 \\
\cline { 2 - 3 } & 1884 & 10.000 \\
\hline İngiltere & --- & 14.900 \\
\hline Fransa & 11.610 & 360 \\
\hline Avusturya & 360 & 10.570 \\
\hline Rusya & 12.500 & --- \\
\hline İsviçre & --- & --- \\
\hline İran & --- & --- \\
\hline Diğer Ülkeler & 2.480 & 35.830 \\
\hline Toplam & 26.950 & \\
\hline
\end{tabular}

67 TNA., F.O. 195/1481, No.1, William Everett'den Dufferin'e, 10 Haziran 1884, ss. 223-245.

68 TNA., F.O. 195/1481, No.1, William Everett'den Dufferin'e, 10 Haziran 1884, ss. 268-270.

69 TNA, F.O. 195/1552, No. 6 (Annex B), George Pollard Devey'den Sir E. Thornton'a, 16 Temmuz 1886, s. 97. 
Tablo 30: 1884 ve 1885 yıllarında Erzurum Vilayeti'nden ihraç edilen temel ürünlerin miktar ve kâr değerleri ${ }^{70}$

\begin{tabular}{|l|l|l|l|l|}
\hline \multirow{2}{*}{$\begin{array}{l}\text { Yabanc1 } \\
\text { Ülkelere }\end{array}$} & \multicolumn{2}{|l|}{1884} & \multicolumn{2}{l|}{1885} \\
\cline { 2 - 5 } & Miktar & Değer $(£)$ & Miktar & Değer $(£)$ \\
\hline Buğday & --- & 3.820 & Qrs 6.600 & 6.000 \\
\hline Kürk & --- & 7.100 & --- & 6.300 \\
\hline $\begin{array}{l}\text { Hayvan postu } \\
\text { ve deri }\end{array}$ & --- & 4.040 & --- & 6.700 \\
\hline Oğlak derisi & --- & --- & 30.000 & 1.100 \\
\hline Keten tohumu & --- & --- & Qrs 9.260 & 10.000 \\
\hline Diğer ürünler & --- & 11.990 & --- & 8.230 \\
\hline Toplam & --- & 26.920 & --- & $38.330^{71}$ \\
\hline
\end{tabular}

1885 yılı ithalatını 1884 yılı ile kıyasladığımızda yaklaşı 34.000£ üzerinde, ihracatın ise $32.000 £$ üzerinde olduğu görülmektedir. 1885 yllında ihracatın artması ise Şam ve Halep ile yapılan canlı hayvan ticaretinden kaynaklanmıştır.

Konsolos Devey’in 1886 yılında kaleme aldığı raporunda Erzurum'daki tüccarların son iki-üç yıldır işlerin azlığı, kârların düşüklüğü, ticaretteki bulanım nedeniyle şikâyet ettiklerini özellikle de perakende satışlarda durumun daha önce dönemlerden daha vahim olduğu belirtmiştir. Buğdaydaki bolluk nedeniyle buğday ve buğdaya bağlı ürünlerin fiyatları düşmüş, ekmek çeyrek peniye satılmıştır. Daha önceki dönemlerde tarım işçilerin hizmetlerinin karşılığında buğday verilirken, buğdaydaki değer düşüklüğünden işçiler bu şekilde ödemeyi reddetmişlerdir. Özellikle 93 Harbi sonrası gerçek mülkiyetin değerinde azalma olmuştur. 1886 yılı toprağın değerini 10 yıl öncesi ile karşılaştırdığımızda toprak değerinin bir hayli düştüğ̈̈, aynı toprağın üçte birine satın alındığı görülmektedir².

70 TNA, F.O. 195/1552, No. 6 (Annex A), George Pollard Devey'den Sir E. Thornton'a, 16 Temmuz 1886, s. 98.

71 TNA, F.O. 195/1552, No. 6 (Annex A), George Pollard Devey'den Sir E. Thornton'a, 16 Temmuz 1886, ss. 98-99.

72 TNA, F.O. 195/1552, No. 6/1, George Pollard Devey'den Sir E. Thornton'a, 16 Temmuz 1886, ss. 90-99. Konsolos Eyres, 1883 yllında yazmış olduğu raporunda harp sonrası Erzurum'da toprak değerinin 4 de 1 oranında azaldığını yazmıştır. Bkz; TNA, F.O. 195/1450, No. 21/1, Harry Charles Augustus Eyres'den G.H. Wyndham'a, 12 Temmuz 1883, s. 111. 
Erzurum Vilayeti’nden ihracatı yapılan başlıca ürünler; buğday, keten tohumu, oğlak derisi, koyundur.

Buğday: 1885 yılında elde edilen hasatın yaklaşık yarısı Marsilya'ya ihraç edilmiş, kalan kısmı ise Trabzon'da satılmıştır.

Keten Tohumu: Keten tohumu, Liverpool'a ihraç edilmiş ve Liverpool ile yeni bir ticaret başlamışır. Pasinler bölgesinde yetiştirilen keten tohumu, tahılın yerini almaya başlamıştır.

Oğlak Derisi: Fransız pazarlarının aranan ürünlerinden biri oğlak derisidir. $\mathrm{Bu}$ ürünün ihracatı Erzurum Vilayeti’nden yapılmıştır. Canlı oğlağın fiyatı Dersim Vilayeti'nde 9 penidir ve Erzurum'da çiftinin fiyatı yaklaşık 1 şilin $(1 \mathrm{~s} / 5 \mathrm{~d})$, İstanbul'da yaklaşı 1 şilin (1s/ld) ve Marsilya'da yaklaşık 2 şilindir $(2 \mathrm{~s} / 6 \mathrm{~d})$. Hükümet, keçi neslinin tükenmesinden korktuğu için bu ürünün ihracatını yasaklamıştır.

Koyun: Koyun ihracatı, vilayette yetiştirilen koyun sayısıyla alakalı olarak artış ya da azalış göstermiştir. 1885 yllında yaklaşık 15.000-16.000 koyun, sınır bölgesindeki İran Kürtlerinden alınmıştır. Bu nedenle vilayette 40.000 koyun artışı olmuştur's.

73 TNA, F.O. 195/1552, No. 6/1, George Pollard Devey'den Sir E. Thornton'a, 16 Temmuz 1886, ss. $90-99$. 


\section{5. İç Ticaret}

İç ticaret kapsamında 1882 yllında ülkenin diğer vilayet ve sancaklarından $158.575 £$ değerinde emtia satın alınmıştır.

Tablo 31: 1882 yll Erzurum'a diğger vilayetlerden alınan emtia ve değerleri ${ }^{*}$

\begin{tabular}{|c|c|c|c|c|}
\hline 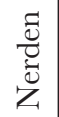 & Emtia & Miktarı & $\begin{array}{l}\text { Değeri } \\
(£)\end{array}$ & Açıklama \\
\hline \multirow{7}{*}{ 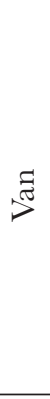 } & Aba (parça) & 1.000 & 650 & Tiftikten üretilen kumaş \\
\hline & Yün (okka) & 60.000 & 1.000 & \\
\hline & Tiftik kumaş1 & --- & 9.000 & İstanbul ve Avrupa'ya ihraç edilmektedir. \\
\hline & Keçi derisi & 10.000 & 1.000 & Avrupa'ya ihraç edilmiştir. \\
\hline & Post & 1.000 & 500 & \\
\hline & Mazı (okka) & 6.000 & 300 & \\
\hline & Kürk (adet) & 8.500 & 2.750 & $\begin{array}{l}\text { 1.500'ü sansar kürkü 700'ü tilki kürkü } \\
\text { Rusya'ya ve Avrupa'ya ihraç edilmiştir. }\end{array}$ \\
\hline \multirow{14}{*}{ 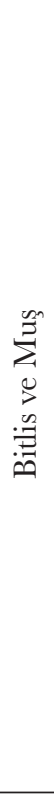 } & Tiftik kumaş1 & 5.000 & 45.000 & Avrupa'ya ihraç edilmiştir. \\
\hline & Mazı (okka) & 300.000 & 18.000 & \\
\hline & Sakız (okka) & 24.000 & 2.700 & Avrupa'ya ihraç edilmiştir. \\
\hline & Keçi derisi & 40.000 & 4.000 & Avrupa'ya ihraç edilmiştir. \\
\hline & $\begin{array}{l}\text { Balmumu } \\
\text { (okka) }\end{array}$ & 3.000 & 450 & Avrupa'ya ihraç edilmiştir. \\
\hline & Renkli pamuk & 21.000 & 3.500 & Yerli pamuktan üretilmiştir. \\
\hline & Boya kökü & 3.000 & 150 & \\
\hline & Palamut & 12.000 & 300 & Derileri tabaklamak için kullanılmıştır. \\
\hline & $\begin{array}{l}\text { Kurutulmuş } \\
\text { meyve }\end{array}$ & --- & 1.000 & \\
\hline & Tereyağ1 & --- & 200 & \\
\hline & Bal & --- & 500 & \\
\hline & Kürk & 70.000 & 14.000 & Sansar ve tilki Avrupa'ya ihraç edilmiştir. \\
\hline & Acı çehre & --- & 2.000 & \\
\hline & Tütün & --- & 2.700 & Avrupa'ya ihraç edilmiştir. \\
\hline
\end{tabular}

74 TNA., F.O. 195/1450, No. 21/1, Harry Charles Augustus Eyres'den G.H. Wyndham'a, 12 Temmuz 1883, ss. 99-109-110. 


\begin{tabular}{|c|c|c|c|c|}
\hline \multirow{9}{*}{ 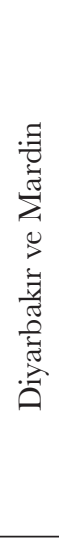 } & Sabun (balya) & 500 & 1.900 & \\
\hline & Deri (parça) & 4.000 & 400 & Küçük miktarda Rusya'ya ihraç edilmiştir. \\
\hline & $\begin{array}{l}\text { Manusa } \\
\text { (parça) }\end{array}$ & 10.000 & 1.200 & $\begin{array}{l}\text { Pamuklu ürünler Manchester pamuğundan } \\
\text { üretilmiştir. }\end{array}$ \\
\hline & İpek (parça) & 100 & 50 & \\
\hline & Pirinç (okka) & 18.000 & 450 & \\
\hline & $\begin{array}{l}\text { Kurutulmuş } \\
\text { meyve }\end{array}$ & --- & 200 & \\
\hline & Mazı (okka) & 6.000 & 200 & \\
\hline & Kürk & 700 & 1.300 & \\
\hline & Tereyağ1 & --- & 200 & \\
\hline \multirow{4}{*}{$\frac{\text { च̃ }}{\text { בี }}$} & İpek parça & 500 & 250 & \\
\hline & Sabun & --- & 3.000 & Zeytinyağından imal edilmiştir. \\
\hline & Manusa & --- & 10.000 & Az miktarda Rusya'ya ihraç edilmiştir. \\
\hline & Baskilı yazma & --- & 500 & \\
\hline \multirow{4}{*}{ 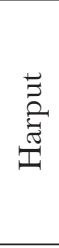 } & İpek (parça) & & & \\
\hline & Şarap & --- & 200 & \\
\hline & $\begin{array}{l}\text { Kurutulmuş } \\
\text { meyve }\end{array}$ & --- & 250 & \\
\hline & Pamuk & --- & 300 & Ham \\
\hline \multirow{5}{*}{ 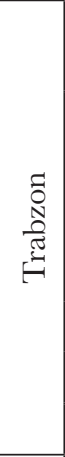 } & Tütün & --- & 7.000 & $\begin{array}{l}\text { Trabzon ve Samsun'dan alınmıştır. } \\
\text { Samsun'dan alınan tütün daha iyi kalitedir. }\end{array}$ \\
\hline & $\begin{array}{l}\text { Kurutulmuş } \\
\text { meyve, } \\
\text { sarımsak, } \\
\text { portakal, } \\
\text { liman, vb. }\end{array}$ & --- & 2.000 & \\
\hline & Sabun & & & \\
\hline & Zeytinyağ1 & --- & 600 & \\
\hline & Öteberi & --- & 1.000 & \\
\hline \multirow{2}{*}{ 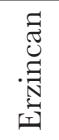 } & $\begin{array}{l}\text { Manusa } \\
\text { (parça) }\end{array}$ & 25.000 & 3.000 & \\
\hline & Öteberi & --- & 1.000 & \\
\hline
\end{tabular}




\begin{tabular}{|c|c|c|c|c|}
\hline$\frac{. \bar{y}}{\frac{\pi}{2}}$ & Manusa & 100.000 & 10.000 & \\
\hline$\frac{\text { 营 }}{\text { 紊 }}$ & $\begin{array}{l}\text { Manusa } \\
\text { (parça) }\end{array}$ & 1.000 & 1.000 & \\
\hline$\frac{\vec{\pi}}{0}$ & $\begin{array}{l}\text { Manusa } \\
\text { (parça) }\end{array}$ & 20.000 & 2.000 & \\
\hline \multicolumn{3}{|c|}{ Toplam } & \multicolumn{2}{|c|}{158.575} \\
\hline
\end{tabular}

Erzurum'un ticaret yaptığı sancak ve vilayetler; Van, Diyarbakır, Mardin, Bitlis, Muş, Halep, Harput, Trabzon, Erzincan, Arapkir, Ayntab, Tokat'trr. Çeşitlilik ve paha değeri bakımından en fazla emtia Bitlis ve Muş'tan alınmıştır. $45.000 £$ 'lik değeri ile en fazla alınan emtia Avrupa'ya ihraç edilmek üzere alınan tiftik kumaşıdır. Diyarbakır, Halep, Erzincan ve Arapkir'den $24.000 £$ değerinde alınan pamuklu emtianın hammaddesi ise Manchester pamuğudur5.

Tablo 32: 1883 yılı Erzurum'a diğer vilayetlerden alınan ürünler ve değerleri ${ }^{76}$

\begin{tabular}{|l|l|l|l|l|}
\hline Vilayet/Sancak & Üün & Miktar & Değer $(£)$ & Toplam \\
\hline Trabzon & Tütün & --- & 5.450 & \\
\hline Trabzon & Kurutulmuş meyveler & --- & 550 & \\
\hline Trabzon & $\begin{array}{l}\text { Sarımsak, limon, } \\
\text { portakal }\end{array}$ & --- & 360 & \\
\hline Trabzon & Sabun & 24.000 okka & 910 & \\
\hline Trabzon & Zeytin Yağ1 & 15.000 okka & 910 & \\
\hline Trabzon & Çeşitli ufak tefek eşyalar & --- & 920 & 9.100 \\
\hline Van & Aba & 200 parça & 140 & \\
\hline Van & Yün & 24.000 okka & 1.090 & \\
\hline Van & Tiftik & 110 balya & 900 & \\
\hline Van & Keçi derisi & 10.000 & 910 & \\
\hline Van & Hayvan postu & 3.000 & 1.090 & \\
\hline
\end{tabular}

75 TNA., F.O. 195/1450, No. 21/1, Harry Charles Augustus Eyres'den G.H. Wyndham'a, 12 Temmuz 1883, ss. 99-120.

76 TNA, F.O. 195/1481, No.1, William Everett'den Dufferin'e, 10 Haziran 1884, ss. 234-235. 


\begin{tabular}{|c|c|c|c|c|}
\hline Van & Koyun derisi & 8.000 & 580 & \\
\hline Van & Mazı & --- & --- & \\
\hline Van & Kürk & 2.450 & 440 & 5.150 \\
\hline Muş, Siirt ve Bitlis & Tiftik & 1.800 balya & 14.730 & \\
\hline Muş, Siirt ve Bitlis & Mazi & 48.000 okka & 2.320 & \\
\hline Muş, Siirt ve Bitlis & Kitre & 14.000 okka & 600 & \\
\hline Muş, Siirt ve Bitlis & Keçi derisi & 20.000 & 2.000 & \\
\hline Muş, Siirt ve Bitlis & --- & 18.000 okka & 2.100 & \\
\hline Muş, Siirt ve Bitlis & Renkli pamuk & 9.000 parça & 1.140 & \\
\hline Muş, Siirt ve Bitlis & Boya kökü & $3.000 \mathrm{okka}$ & 110 & \\
\hline Muş, Siirt ve Bitlis & Palamut & $3.000 \mathrm{okka}$ & 80 & \\
\hline Muş, Siirt ve Bitlis & Kurutulmuş meyveler & --- & 450 & \\
\hline Muş, Siirt ve Bitlis & Tereyağı & -- & --- & \\
\hline Muş, Siirt ve Bitlis & Bal & --- & --- & \\
\hline Muş, Siirt ve Bitlis & Kürk & 13.650 & --- & \\
\hline Muş, Siirt ve Bitlis & Tütün & --- & 2.380 & 25.910 \\
\hline $\begin{array}{l}\text { Diyarbakır ve } \\
\text { Mardin }\end{array}$ & Sabun & -- & --- & \\
\hline $\begin{array}{l}\text { Diyarbakır ve } \\
\text { Mardin }\end{array}$ & Deri & 2.500 parça & 230 & \\
\hline $\begin{array}{l}\text { Diyarbakır ve } \\
\text { Mardin }\end{array}$ & Manusa & 5.0000 parça & 500 & \\
\hline $\begin{array}{l}\text { Diyarbakır ve } \\
\text { Mardin }\end{array}$ & İpek & $\begin{array}{ll}-- \\
---\end{array}$ & -- & \\
\hline $\begin{array}{l}\text { Diyarbakır ve } \\
\text { Mardin }\end{array}$ & Pirinç & 6.000 okka & 150 & \\
\hline $\begin{array}{l}\text { Diyarbakır ve } \\
\text { Mardin }\end{array}$ & Kurutulmuş meyveler & -- & 90 & \\
\hline $\begin{array}{l}\text { Diyarbakır ve } \\
\text { Mardin }\end{array}$ & Mazı & -- & -- & \\
\hline $\begin{array}{l}\text { Diyarbakır ve } \\
\text { Mardin }\end{array}$ & Tereyağ1 & 600 okka & 30 & 1.000 \\
\hline Harput & İpek & 300 parça & 410 & \\
\hline Harput & Şarap & 200 fiçı/varil & 360 & \\
\hline
\end{tabular}




\begin{tabular}{|c|c|c|c|c|}
\hline Harput & Kurutulmuş meyveler & --- & 180 & \\
\hline Harput & Ham pamuk & --- & 450 & 1.400 \\
\hline Halep & İpek & 500 parça & 340 & \\
\hline Halep & Mavi boyalı pamuk & 1000 parça & 140 & \\
\hline Halep & Sabun & 54.000 parça & 2.870 & \\
\hline Halep & Manusa & 4.000 parça & 700 & \\
\hline Halep & $\begin{array}{l}\text { Halep’ye baskılanmış } \\
\text { kumaş }\end{array}$ & 2.500 & 220 & \\
\hline Halep & Boyalı ipek (silk made up) & 500 & 290 & 4.560 \\
\hline Erzincan & Manusa & 20.000 parça & 2.910 & \\
\hline Erzincan & Çeşitli ufak tefek eşyalar & --- & 450 & \\
\hline Erzincan & $\begin{array}{l}\text { Manchester'dan alınıp } \\
\text { baskı yapılan kumaş }\end{array}$ & 10.000 parça & 360 & 3.720 \\
\hline Arapkir & Manusa & 50.000 parça & 5.500 & 5.500 \\
\hline Ayntab & Manusa & 5.000 parça & 450 & 450 \\
\hline Tokat & $\begin{array}{l}\text { Manchester'dan alınıp } \\
\text { Tokat'ta baskı yapılan } \\
\text { kumaş }\end{array}$ & 100.000 kare & 1.360 & 1.360 \\
\hline Rize & Keten & 21.000 parça & 5.730 & 5.730 \\
\hline Bağdat & Hurma & 600 balya & 680 & 680 \\
\hline Karahisar & Şap & 600 balya & 820 & 1.120 \\
\hline Palu & $\begin{array}{l}\text { Yerli demirden üretilmiş } \\
\text { saban }\end{array}$ & --- & 300 & 200 \\
\hline Palu & Kurutulmuş meyveler & --- & 200 & 65.880 \\
\hline
\end{tabular}

1883 yllında Erzurum'un diğer vilayetlerden aldığı ürünleri daha önceki yıllar ile karşılaştırıldığımızda ürünlerde önemli bir düşüş olduğu görülmektedir. Özelikle İskenderiye ve Trabzon limanı üzerinden İstanbul ve Avrupa pazarlarına sevk edilen tiftiğin alımında azalma olmuştur. Van'dan 1882 yılında alınan $9000 £^{\prime}$ lik tiftik 1883 yllında 900£'e düşmüştür. Yine tiftik ticaretinde Bitlis ve Muş'tan alınan tiftikte de düşüs meydana gelmiştir. Ayrıca daha önceki yıllarda Van Vilayeti'nden önemli miktarda mazı alınırken 1883 yılında Van'da mazının olmaması nedeniyle alınamamıştır. Keçi derisi, boyalı pamuk, palamut-pelit ve kürk alımlarında benzer düşüş görülmüştür. Yine aynı yıl Diyarbakır'dan alınan manusalar 1882 yılına oranla \%50 oranında düşmüştür. Diyarbakır'dan alınan, pirinç, kurutulmuş meyve, tereyağı vb. günlük tüketim ürünlerinin miktarında 
önemli ölçüde düşüş yaşanmıştır. Esas düşüş Harput'tan alınan ipekte olmuştur. 1882 ylında Erzurum'a Halep’ten $10.000 £$ değerinde manusa alınmasına karşın 1883 yılında aynı kalitede yalnızca $400 £$ değerinde ürün alınmıştır. Alımlardaki azalmanın nedeni ise aynı dönemde Erzincan ve Arapkir'deki bu endüstri/sanayi kolunun canlanmasıdır. 1883 yılında taleplerde azalma olduğu insanların ürünü talep etmediği daha doğrusu satın almaya gücü yetmediği görülmektedir. 1882 yllı Erzurum'a alınan manusanın toplam değeri yaklaşık $26.000 £$ iken 1883 yllında $10.000 £^{\prime}$ dir ve yaklaşık \%61'lik bir düşüş yaşanmıştır. 1883 yllında hemen hemen tüm ürünlerin satışında-alımında talep azlığı nedeniyle düşüş olmuştur. 1883'de bir önceki yıldan farklı olarak Rize, Bağdat, Karahisar ve Palu'dan ürün alınmıştır. 1883 yllında bir önceki yılda olduğu gibi ürün çeşitliliği ve paha değeri bakımından en fazla ürün Bitlis ve Muş'tan alınmıştır.

Tablo 33: 1882 ve 1883 yılları Erzurum Vilayeti’ne diğer vilayetlerden alınan emtianın karşılaştırmalı istatistiğ $\mathrm{i}^{\mathrm{in}}$

\begin{tabular}{|l|l|l|l|}
\hline Vilayet/Sancak & $1882(\mathfrak{})$ & $1883(£)$ & Düşüs(£) \\
\hline Trabzon & 11.600 & 9.100 & 2.500 \\
\hline Van & 15.200 & 5.150 & 10.050 \\
\hline Muş, Siirt ve Bitlis & 94.500 & 25.910 & 68.590 \\
\hline $\begin{array}{l}\text { Diyarbakır ve } \\
\text { Mardin }\end{array}$ & 5.900 & 1.000 & 4.900 \\
\hline Harput & 1.625 & 1.400 & 225 \\
\hline Halep & 13.750 & 4.560 & 9.190 \\
\hline Erzincan & 4.000 & 3.720 & 280 \\
\hline Arapkir & 10.000 & 5.500 & 4.500 \\
\hline Ayntab & 1.000 & 450 & 550 \\
\hline Tokat & 2.000 & 1.360 & 640 \\
\hline Toplam & 159.575 & 58.150 & 104.425 \\
\hline
\end{tabular}


Tablo 34: 1884-1885 yılları Erzurum Vilayeti’ne diğer vilayetlerden alınan emtianın miktarı ve kâr değerleri ${ }^{8}$

\begin{tabular}{|l|l|l|l|l|}
\hline \multirow{2}{*}{ Ürün } & \multicolumn{2}{|c|}{1884} & \multicolumn{2}{c|}{1885} \\
\cline { 2 - 5 } & \multicolumn{1}{|c|}{ Miktar } & \multicolumn{1}{|c|}{ Değer(£) } & \multicolumn{1}{c|}{ Miktar } & \multicolumn{1}{c|}{ Değer(£) } \\
\hline Manusa & 118.000 Parça & 11.860 & 214.000 Parça & 20.730 \\
\hline Kürk-Furs & & 8.020 & --- & 5.400 \\
\hline Tiftik & 882 Balya & 5.290 & --- & \\
\hline ----- & 2.150 Cwt & 3.610 & 1.245 Cwt & 2.280 \\
\hline $\begin{array}{l}\text { Keçi/Koyun } \\
\text { Derisi }\end{array}$ & 42.000 & 3.870 & 15.000 & 1.060 \\
\hline Diğer ürünler & --- & 29.850 & --- & 22.580 \\
\hline \multicolumn{2}{|r|}{ Toplam } & 62.500 & Toplam & 52.050 \\
\hline
\end{tabular}

Manusa: Yerli üretim pamuk hem miktar hem de fiyat olarak iki katına çıkmıştır. Arapkir'e 1884 yılında 6.000£ değerinde 60.000 parça pamuk; 1885 yllında da $11.000 £$ değerinde 120.000 parça pamuk gönderilmiştir. Halk daha çok renklerin dayanıklılığı ve sağlamlığı nedeniyle yerli ürünleri tercih etmiştir. Yerli ürünler fiyat noktasında Manchester ürünleri ile başarılı bir şekilde rekabet ederken, rekabeti ortadan kaldırmak için perakende alımlarda İngiliz baskılı ürünlerde (27 inçin her arşınında 26 para değerinde) indirime gidilmiştir.

Tiftik: Erzurum'a daha önceki yıllarda Van, Muş, Bitlis ve Siirt'den tiftik alımı yapılırken 1885 yılında bu bölgelerden hiç tiftik alınamamış, aynı yıl sadece Diyarbakırlı tüccarlardan tiftik alımı yapılmıştır. Daha önceki yıllarla karşılaştırdığımızda tiftik ticaretinde önemli bir azalma olduğu hatta bitme noktasına gelindiği görülmektedir ${ }^{79}$.

Savaş sonrası dönemde önemli miktarda at, koyun, sığır, öküz, inek, Halep, Şam ve Mısır’a satılmış, 1882 yılında ise canlı hayvan satışında ambargo uygulanmıştır ${ }^{80}$.

TNA, F.O. 195/1552, No. 6 (Annex A), George Pollard Devey'den Sir E. Thornton'a, 16 Temmuz 1886, s. 99.

79 TNA, F.O. 195/1552, No. 6/1, George Pollard Devey'den Sir E. Thornton'a, 16 Temmuz 1886, ss. 90-99.

80 TNA, F.O. 195/1450, No. 21/1, Harry Charles Augustus Eyres'den G.H. Wyndham'a, 12 Temmuz 1883, ss. 99-120. 
Tablo 35: 1883 yılı Erzurum Vilayeti'nden diğer vilayetlere satılan emtianın değer ve miktarları

\begin{tabular}{|l|l|l|}
\hline Ürün & Miktar & Değer $(£)$ \\
\hline Pastırma & $12.000($ okka $)$ & 4.540 \\
\hline İnek ve öküz & 8.200 & 19.000 \\
\hline Koyun & 25.000 & 15.400 \\
\hline At & 1.500 & 8.170 \\
\hline Eyer takımı & --- & 350 \\
\hline İç yağ1 & --- & 250 \\
\hline Toplam & & 47.710 \\
\hline
\end{tabular}

Koyunların büyük bir kısmı tanesi 18 şiline Halep’e satılmıştır. Eyer takımları Muş, Bitlis, Siirt ve yakın bölgelere, iç yağı Trabzon'a satılmıştırı.

Tablo 36: 1884 ve 1885 yılları Erzurum Vilayeti'nden diğer vilayetlere satılan temel emtianın miktarı ve kâr değerleri ${ }^{\text {g2 }}$

\begin{tabular}{|l|l|l|l|l|}
\hline \multirow{2}{*}{ Ürün } & \multicolumn{2}{|c|}{1884} & \multicolumn{2}{c|}{1885} \\
\cline { 2 - 5 } & Miktar & Değer $(£)$ & Miktar & Değer $(£)$ \\
\hline Buğday & --- & & Qrs 6.600 & 6.000 \\
\hline Koyun & 60.000 & 46.360 & 100.000 & 59.090 \\
\hline Öküz-İnek & 3.000 & 5.500 & 5.000 & 11.250 \\
\hline At & 2.000 & 10.910 & 1.200 & 5.500 \\
\hline Pastırma & 2.400 Balya & 6.550 & 2.800 balya & 9.000 \\
\hline $\begin{array}{l}\text { Diğer Ürünler } \\
\text {--- }\end{array}$ & 2.800 & --- & 2.010 \\
\hline Toplam & & 72.120 & & 92.850 \\
\hline
\end{tabular}

1884 yılında Erzurum'dan diğer vilayetlere satılan ürünlerin toplam değeri $72.120 £, 1885$ yllında Erzurum'dan diğer vilayetlere satılan ürünlerin toplam

81 TNA, F.O. 195/1481, No.1, William Everett'den Dufferin'e, 10 Haziran 1884, s. 236.

82 TNA, F.O. 195/1552, No. 6 (Annex A), George Pollard Devey'den Sir E. Thornton'a, 16 Temmuz 1886, s. 98. 
değeri $95.350 £$ 'dir. 1885 yılında canlı hayvan sayısına bağlı olarak ihracat artmıştır. Bu azalış Şam ve Halep ile yapılan canlı hayvan ticaretinden kaynaklanmıştır.

\section{Tarim}

Topraklarının büyük bir bölümü verimli olan ve geniş ovaları bulunan Erzincan ve Pasinler Sancağı'nda daha çok tahıl yetiştirilmiştir. Konsolos, toprağın doğru düzgün sürülmediğini ve neredeyse hiç gübrelenmediği için mevcut arazide beş kat buğday, altı kat arpa üretildiğini, uygun koşullarda ekim yapıldığı takdirde topraktan 30 kat verim elde edilebileceğini belirtmiştir.

Vilayetin toprak verimi ve üretim açısından en zengin bölgesi Bayezid Sancă̆g'dır. 93 Harbi sonrasında halkın can ve mal güvenliği konusunda tedirgin olması ve buna bağlı olarak nüfusun azalmasıyla tarımda düşüş meydana gelmiştir. Tarımsal verim açısından Bayezid Sancağı'ndan sonra gelen Merkez Erzurum Sancağı'nın üretim açısından birinci sırada olduğu görülmektedir. Merkez Sancağa bağlı Tercan ve Ova Kaymakamlıkları sancağın diğer kazalarına oranla daha verimlidir. Tercan'dan elde edilen buğdayın yaklaşık yarısı, Ova ve Bayburt'tan elde edilen buğdayın üç de biri Trabzon'a satılmıştır.

Tablo 37: 1881 ylı Erzurum Vilayeti ortalama tahıl miktar1 ${ }^{13}$

\begin{tabular}{|l|l|l|l|l|l|l|}
\hline \multicolumn{1}{|c|}{ Ürün } & \multicolumn{1}{c|}{ Ölçü } & \multicolumn{1}{c|}{ Erzurum } & \multicolumn{1}{c|}{ Bayezid } & Erzincan & Bayburt & Toplam \\
\hline Buğday & Kilest & 1.600 .000 & 500.720 & 537.130 & 825.000 & 3.462 .850 \\
\hline Arpa & Kile & 815.000 & 190.390 & 170.000 & 270.000 & 1.445 .390 \\
\hline Çavdar & Kile & 90.000 & --- & --- & 61.000 & 151.000 \\
\hline Darı & Kile & 25.000 & 9.060 & 10.74 & 8.000 & 52.800 \\
\hline $\begin{array}{l}\text { Keten } \\
\text { Tohumu }\end{array}$ & Kile & 7.000 & 3.700 & 2.520 & 100 & 13.320 \\
\hline Fasulye & & 400 & --- & 4.810 & --- & 5.210 \\
\hline
\end{tabular}
muz 1883, s. 114.

84 Ölçülerin değerinin yeniden belirlendiği 24 Eylül 1881 tarihli kararnâme ile 1 yeni kile=100 yeni şinik=100 ölçek $=1.000$ yeni kutu 10.000 zarf olarak belirlenmiştir. Bkz; Cengiz Kallek, "Kile", s. 570 . 


\begin{tabular}{|c|c|c|c|c|c|c|}
\hline Nohut & \multirow[t]{3}{*}{ Kile } & \multirow[t]{3}{*}{900} & \multirow[t]{3}{*}{200} & \multirow[t]{3}{*}{1.510} & \multirow[t]{3}{*}{--- } & \multirow[t]{3}{*}{2.160} \\
\hline Mercimek & & & & & & \\
\hline Bakla & & & & & & \\
\hline Pirinç & Kile & --- & --- & --- & 3.000 & 3.000 \\
\hline \multicolumn{7}{|l|}{$\begin{array}{l}\text { Kokoroz- } \\
\text { Misir }\end{array}$} \\
\hline \multicolumn{7}{|l|}{ Ceviz } \\
\hline Küşne & Kile & 3.500 & - & - & 2.900 & 6.400 \\
\hline \multicolumn{2}{|c|}{ Toplam } & 2.550 .800 & 704.070 & 729.450 & 1.179 .000 & 5.163 .370 \\
\hline
\end{tabular}

Tablo 38: 1881 yılı Erzurum Vilayeti ortalama meyve-sebze miktar1 ${ }^{85}$

\begin{tabular}{|l|l|l|l|l|l|l|}
\hline Ürün & Ölçü & Erzurum & Bayezid & Erzincan & Bayburt & Toplam \\
\hline Sebze & Okka $^{86}$ & 1.116 .000 & 101.000 & 383.50 & 77.550 & 1.678 .050 \\
\hline Tütün & Okka & - & - & 1.790 & - & 1.790 \\
\hline Pamuk & Okka & - & - & 14.325 & 1.320 & 15.645 \\
\hline Meyve & Okka & 616.145 & 9.150 & 796.600 & 833.030 & 2.244 .925 \\
\hline Çiriş & Okka & - & - & 300 & - & 300 \\
\hline & & 1.732 .145 & 110.150 & 1.196 .515 & 911.900 & 3.940 .770 \\
Toplam & & & & & & \\
\hline
\end{tabular}

Konsolos Eyres, Erzurum Vilayeti’nin genel üretim gücünde 1873-1883 yılları arasında herhangi bir artış olmadığını belirtmiştir. Yaşanan kıtlık ve çekirge saldırısı nedeniyle alınan verim yıl yıl değişiklik göstermiştir. Ancak Konsolos Eyres, kıtlık gibi bol hasatın da çiftçiler için büyük talihsizlik olduğunu belirtmiştir. Zira, vilayette mahsulün fazla olması bazı problemlere neden olmuştur. Erzurum için önemli gelir kaynağı olan buğdayın fiyatı bolluk sebebiyle bir hayli düşmüştür. Erzurum'un denize uzak olması, ulaşımın ise çok pahalı ve zor olması nedeniyle mahsullerini satamayan çiftçiler mali açıdan zorluk yaşamışlardır. Erzurum'da verimin fazla olduğu bir yılda buğdayın bir buşeli ${ }^{87} 10$ kuruş (1s/10d) iken bazı

85 TNA, F.O. 195/1450, No. 21/1, Harry Charles Augustus Eyres'den G.H. Wyndham'a, 12 Temmuz 1883, s. 114.

86 Okka/ûkıyye, 1283 gramlık ağırlık ölçüsüdür. Bkz; Ferit Devellioğlu, a.g.e., s. 1118.

87 Buşel (Bushel), İngiltere'de yaklaşık 36.4'e Amerika'da 35.2 litreye denk gelen bir ölçü birimidir. Bkz; https://dictionary.cambridge.org/tr/s\%C3\%B6zl $\% \mathrm{C} 3 \% \mathrm{BCk} /$ ingilizce/bushel 
dönemlerde buğdayın bir buşeli 50 (9s) kuruşa kadar yükselmiş, yıllık ortalama fiyatının ise 20 kuruş olduğu görülmüştür. Arpanın fiyatı yıl içinde ortalama 6 kuruştan 17 kuruşa $(1 \mathrm{~s} / 1 \mathrm{~d}, 3 \mathrm{~s} / 2 \mathrm{~d})$ kadar yükselmiş ve dönem dönem değişiklik göstermiştir. Diğer sancaklar ile karşılaştırıldığında Bayezid'de hububat çok ucuz olduğu, buğdayın bir buşeli 7 kuruşa (1d/4s) ve arpanın fiyatı 3-4 (7d-9d) kuruşa satıldığ 1 olmuştur ${ }^{88}$.

1882 yılı ve takip eden 1883 yılında oldukça verimli hasat yapılmıştır. Konsolos Everett, olağanüstü iyi hasattan sonra ulaşım zorluğu nedeniyle ürünlerin halkın elinde kaldığını, bu durumu kâra dönüştüremediklerini, bolluk nedeniyle fiyatların düştügünü bunun da mali yapıyı olumsuz etkilediğini belirtmiştir. Erzurum Vilayeti'nde uygun mevsimde yapılan iyi hasat bile ticareti canlandıramamıştır.

1883 yılı vilayette hasat edilen tahıl miktarı; Erzurum Sancağı 1.394 .020 kile; Bayburt Sancağı 717.380 kile; Erzincan Sancağı 391.450 kile; Bayezid Sancağı 335.570 kile; toplamda 2.838.420 kiledir (5.178.871 buşel). Konsolos Everett, Konsolos Eyres'e atıfta bulunarak, eğer ortalama bir yılda 3.507.537 buşel tahıl üretiliyorsa, 1883 yılında 1.671 .334 buşel fazla tahıl elde edildiğini belirtmiştir. Tahıllar, yüksek fiyatlarla daha fazla para getirecek yıllar için stoklanmıştır. 18831884 yılı şiddetli kar yă̆ışı, ekinleri dondan kurtarmıştır. 1884 yılı baharının erkenden gelmesi 93 Harbi sonrası en düşük fiyatların görülmesini sağlamıştır. Buğdayın 22 okkalık kilesi 10 kuruş (1s/10 1/2 d), sarıbaş 9 kuruş, arpanın birinci kalitesi 7 kuruş (1s/8 1/4 d), ikinci kalitesi 6 kuruştur (1d/1 1/2 d). Konsolos Everett, vilayetin doğu bölgelerinde bu ürünlerin daha uygun fiyatlara alınabileceğini, kısa süre önce bir tüccarın Pasinler bölgesinden kilesi 4 kuruşa (9d) oldukça fazla arpa aldığını, bu uygun fiyatların devam edeceğini hatta fiyatlarda düşme olabileceğini belirtmiştir ${ }^{39}$.

\section{Hayvancılık}

Konsolos Eyres, 1881 yılı Erzurum Vilayeti'nde bulunan hayvan türü ve sayısına dair bilgi vermiştir. Ancak 1880 yılının hayvan stoku ile ilgili karşılaştırma yapabileceğimiz bir istatistiğin olmadığını belirten Eyres, hayvan sayısında son

$(13.11 .2018)$

88 TNA, F.O. 195/1450, No. 21/1, Harry Charles Augustus Eyres'den G.H. Wyndham'a, 12 Temmuz 1883, ss. 99-120.

89 TNA, F.O. 195/1481, No.1, William Everett'den Dufferin'e, 10 Haziran 1884, ss. 223-245. 
yıllarda artış olduğunu ancak sayının hala 93 Harbi öncesi rakamlara ulaşmadığını belirtmiştir.

Tablo 39: 1881 yll Erzurum Vilayeti’nde bulunan hayvanların türü ve sayıs1 ${ }^{90}$

\begin{tabular}{|l|l|l|l|l|l|}
\hline Emtia & Erzurum & Bayezid & Erzincan & Bayburt & Toplam \\
\hline Öküz-İnek & 249.280 & 34.519 & 33.560 & 31.530 & 348.889 \\
\hline Sı̆̆ır & 31.240 & 5.624 & 7.660 & 2.130 & 46.654 \\
\hline At & 12.278 & 10.862 & 7.117 & 2.748 & 33.005 \\
\hline Koyun & 505.000 & 160.000 & 200.000 & 200.000 & 1.065 .000 \\
\hline Keçi & 198.598 & 26.315 & 99.897 & 133.446 & 458.256 \\
\hline Katır & 320 & 50 & 1.324 & 375 & 2.069 \\
\hline Eşek & 19.400 & 1.208 & 15.179 & 1.760 & 37.547 \\
\hline Deve & - & 75 & - & 40 & 115 \\
\hline Arı kovanı & 14.500 & 150 & 7.537 & 18.891 & 41.078 \\
\hline Toplam & 1.030 .623 & 238.803 & 372.274 & 390.920 & 2.032 .613 \\
\hline
\end{tabular}

Tablo 40: Erzurum Vilayet Salnâmesine göre 1881 yılı Erzurum Vilayeti'nde bulunan hayvanların ve hayvanlardan imal edilen emtianın türü ve sayıs1 ${ }^{91}$

\begin{tabular}{|l|l|l|l|l|l|l|}
\hline Sancak & Keçi Kılı & Yapağı & $\begin{array}{l}\text { Öküz ve } \\
\text { Manda } \\
\text { Derisi } \\
\text { (Adet) }\end{array}$ & $\begin{array}{l}\text { Keçi } \\
\text { Derisi } \\
\text { (Adet) }\end{array}$ & $\begin{array}{l}\text { Arı } \\
\text { Kovanı } \\
\text { (Adet) }\end{array}$ & $\begin{array}{l}\text { Deve } \\
\text { (Adet) }\end{array}$ \\
\hline Erzurum & 97.900 & 145.000 & 13.600 & 37.800 & 14.500 & 175 \\
\hline Bayezid & 9.000 & 50.000 & 7.800 & 13.600 & 150 & 1300 \\
\hline Erzincan & 38.000 & 76.000 & 6.000 & 33.500 & 9.537 & 40 \\
\hline Bayburt & 29.200 & 40.000 & 8.700 & 47.000 & 16.891 & $415^{92}$ \\
\hline Toplam & 175.200 & 311.000 & 36.100 & 131.900 & 44.078 & \\
\hline
\end{tabular}

90 TNA, F.O. 195/1450, No. 21/1, Harry Charles Augustus Eyres'den G.H. Wyndham'a, 12 Temmuz 1883, s. 116.

91 Salnâme-i Vilâyet-i Erzurum, H. 1299 (M. 1882), Def'a 9, s. 163.

92 Konsolos Eyres'in raporu ile Erzurum Vilayet Salnâmesinde yer alan aynı dönem ve aynı türü kapsayan veriler arasında sayısal bir takım farklılıklar olduğu tespit edilmiştir. Erzincan ve Bayburt Sancakları arı kovanı adedi ile Bayezid Sancağı deve sayısı bahsi geçen farklılıklardır. Bu du- 
Eyres 1882 yılı Erzurum Vilayeti’ndeki koyun sayısını vermiştir. Erzurum Sancă̆g'nda 450.164; Bayezid Sancağı'nda 143.084; Erzincan Sancağı'nda 152.220; Bayburt Sancağı'nda 192.814 koyun olduğunu belirtmiştir. Bu rakamları bir önceki yıl ile karşılaştırdığımızda yaklaşık 126.000'lik bir azalmanın olduğunu görmekteyiz. Bu azalma ise, 1881-1882 kışının oldukça sert geçmesi ve yemde kıtlik olmasından kaynaklanmıştır ${ }^{\text {s. }}$.

Tablo 41: 1881, 1882 ve 1883 yılları için vilayetteki koyun sayıs1 ${ }^{94}$

\begin{tabular}{|l|l|l|l|}
\hline Sancak & 1881 & 1882 & 1883 \\
\hline Erzurum & 505.000 & 450.164 & 479.946 \\
\hline Erzincan & 200.000 & 152.220 & 155.690 \\
\hline Bayburt & 200.000 & 192.814 & 197.662 \\
\hline Bayezid & 160.000 & 143.084 & 172.451 \\
\hline Toplam & 1.065 .000 & 938.282 & 1.005 .749 \\
\hline
\end{tabular}

Vilayetteki koyun sayısına bakıldığında 3 yıl içinde rakamlarda baharın kuru geçmesi, kışın ise ılık geçmesine bağlı olarak dalgalanmalar yaşanmıştır. 1883 yılı koyun sayısı 1882 yılından daha iyi, ancak 1881 yılı koyun sayısının son iki yıldan daha yüksek olduğu görülmüsstür». Bayezid Sancağı'nda 1872 yılında koyun sayısı 300.000 iken 1883 yılında koyun sayısının yaklaşı yarısı kadar olduğu görülmektedirø.

1883 yllı ilkbaharında Erzurum Sancağı'nda ve vilayetin doğu kısımlarında sığır vebası görülmüş, sığır ölümleri yaşanmıştır"9. Konsolos Everett, halkın bu konudaki bilgisizliği ve temizlik önlemlerindeki eksiklikler nedeniyle ölümlerin şaşırtıcı olmadığını, ancak sığır vebasının vilayet dâhilinde hafif

rum Konsolos Eyres'in resmi verileri kaydederken hata yapmış olma ihtimali akla getirmektedir.

TNA, F.O. 195/1450, No. 21/1, Harry Charles Augustus Eyres'den G.H. Wyndham'a, 12 Temmuz 1883, s. 116.

94 TNA, F.O. 195/1481, No.1, William Everett'den Dufferin'e, 10 Haziran 1884, s. 240.

95 TNA, F.O. 195/1481, No.1, William Everett'den Dufferin'e, 10 Haziran 1884, s. 241.

96 TNA, F.O. 195/1450, No. 21/1, Harry Charles Augustus Eyres'den G.H. Wyndham'a, 12 Temmuz 1883, ss. 99-120.

97 TNA, F.O. 195/1481, No.1, William Everett'den Dufferin'e, 10 Haziran 1884, ss. 223-245. Tanin Gazetesi yazarlarından Ahmet Şerif, sığır vebasının 93. Harbi'nden sonra muhacirler tarafindan getirilen bir felaket olduğunu belirtmiştir. 93 Harbi sonrası Osmanlı Devleti’nin doğu vilayetlerinde büyük miktarda kayıplara sebebiyet veren bu salgın, ülkenin pek çok yerine yayılmış ve ülke genelinde görülme sıklığı bu tarihten sonra artmıştır. Bkz; Mehmet Ak, "Osmanlı Devleti'nde Veba-i Bakarî (Sığır Vebası)", OTAM, S. 39, Bahar 2016, s. 219. 
formda görüldüğünü, 1884 yılı itibariyle hastalığın tamamen ortadan kalktığını belirtmiştir ${ }^{98}$.

\section{Endüstri}

Erzurum Vilayeti'nde ülkenin diğer bölgelerinde olan sıradan esnaflar bulunmakla birlikte istisna olarak İspir, Kelkit, Şiran, Kiğı, Pasinler ve Tercan Kazalarında halı üretilmiş, vilayetin önde gelenleri ise tarımla ilgilenmişlerdir. Kiğı Kazasında dokuma ürünler, Bayburt'ta pamuk ve yünden divan örtüleri yapılmış ve Kürt halıları dokunmuştur. Erzincan'da imitasyon İran halıları ve çeşitli pamuklu ürünler imal edilmiştir. Konsolos Eyres, bölgede başka önemli endüstri dalının olmadığını, bölgenin mineral açısından çok zengin olmasına rağmen, hükümetin maden çalışmalarını sürekli reddettiğini belirtmiştir.

\section{Kamu Çalışmaları}

Kamu çalışmaları dâhilinde 1881 yılında Erzurum'da yaklaşık 1.000 metrelik bir yol yapılmıştır. Trabzon'dan Erzurum'a uzanan anayol tamir edilmiş ve Bayburt'ta iki küçük köprü inşa edilmiştiris. 1885 yılında Bayezid'e uzanan telgraf hattı tamamlanmış ve İran ile doğrudan posta servisi kurulmuştur. 1885 yılı yazında, Erzurum'u Kiğı ve Kozluca bölgelerinden geçerek Erzincan’a bağlayan ikinci bir telgraf hattı kurulması öngörülmüştür ${ }^{100}$.

Trabzon'dan Erzurum'a uzanan yolun tamiri sırasında Erzurum İngiliz Konsolosluğu'ndan yazılan gönderilerde yolun tamamlanması halinde bölgeye yapacağı muazzam katkılardan bahsedilmiştir. Bölgenin temel geçim kaynaklarından biri olan tahılın Trabzon vasıtasıyla satılmasını sağlayacak olan bu yol yetersiz onarım ve güvenlik hususundaki problemlerden dolayı beklentiyi karşılayamamıştır. Yerli tahıl fiyat olarak Rusya'dan ya da başka yerlerden ithal edilen tahıllar ile rekabet edememiştir. Konsolos Everett, bu problemle başa çıkmanın tek başarılı yolunun Erzincan ve Sivas ya da Tokat tarafindan Samsun limanına uzanan demiryolu hattının yapılması olduğunu belirtmiştir ${ }^{101}$.

100 TNA, F.O. 195/1481, No.1, William Everett'den Dufferin'e, 10 Haziran 1884, ss. 223-245.

101 TNA, F.O. 195/1481, No.1, William Everett'den Dufferin'e, 10 Haziran 1884, ss. 268-270. 


\section{Sonuç}

93 Harbi, ülkenin genel ticareti üzerinde felakete yol açmıs, iktisadi ve sosyal hayatta önemli problemlere sebebiyet vermiştir. Özellikle savaşın cereyan ettiği ya da yakından hissedildiği coğrafyalarda hayat durma noktasına gelmiştir. Bölgenin kısa süreli işgali, Rusların Erzurum sınırına dayanması bölgede endişe havası yaratmış, özellikle Bayezid Sancağında toprak ve ev fiyatları üçte bir, dörtte bir oranında gerilemiş, değer kaybetmiştir. Savaş sonrası transit ticaret geliri dörtte bir oranında azalmıştır. Yaşanan durgunluk tüccar sınıfı arasında endişeye neden olmuştur. Tüccarlar, harp sonrası nüfusun yoksullaşmasına bağlı olarak ellerinde sadece zorunlu tüketim mallarını bulundurmuslar, pahalı ithal malları tedarik edecek sermaye bulamamışlardır. Ancak bu noktada 93 Harbi'nden önce de bölgede ticaretin aşağıya doğru bir düşüş gösterdiği göz ardı edilmemelidir.

Poti ve Batum'dan Tiflis'e ulaşan demiryolu ticaret güzergâhının ön plana çımması, savaş ve mukabilinde İran ulaşımının kısmi kaybı Erzurum ticaretini oldukça olumsuz etkilemiş, ticaretin azalmasına sebebiyet vermiştir.

Harp sonrası Erzurum'dan İngiltere, Fransa, Avusturya, İsviçre, İran, Rusya gibi ülkelere ihracat yapılmıştır. Ancak harp öncesi ile karşılaştırdığımızda özellikle Avrupa'ya yapılan ihracatın savaş sonrası dönemde üçte bir oranında azaldığı görülmektedir. İhraç edilen başlıca ürünler ise kürk, deri, keten, mazı, pamuklu mallar, ipek, sabun, kumaş, yünlü ürünler, çanak çömlek, cam eşya, hırdavat, kibrit, çay, canlı hayvan, buğday, misina, oğlak derisi, keten tohumu ve hayvan postudur. Ancak yapılan ihracatta bizzat Erzurum'da üretilen, imal edilen ürünlerin payının çok az olduğu görülmektedir. Erzurum'da üretilen, imal edilen ve satışı yapılan başlıca ürünler kürk, deri, mum, tutkal/yapıştırıcı, sakız, misina, deri ve buğdaydır. Erzurum Vilayeti daha çok imal edip sattığı ürünlerden değil, transit ticaret gelirlerinden kazanç elde etmiş̧ir.

Harp öncesi ve harp sonrası dönemde Erzurum'a ihracat yapan, Erzurum pazarında en büyük paya sahip olan ülke İngiltere'dir. İhracat yapan diğer ülkeler İran, Rusya, Fransa, Avusturya, Amerika, İsviçre, Almanya ve İtalya'dır. Ingiltere'den çay, biber, demir, bakır, kurşun ve kalay alaşımı kap, şap, kırmız, çivit, pazen, dikiş ipliği, pamuk iplik, patiska, yatak örtüsü, kumaş, kökboyası, pazen, tülbent, kaba pamuklu kumaş ve yastık-minder kılıfi ithal edilen başlıca ürünlerdendir. İran'dan mazı, halı, şal, deri, ipek, tömbeki, yün, misina, ipek iplik, kına, zırnık, halı, pirinç, kurutulmuş meyve, pamuk ithal edilmiştir. Rusya'dan keten, sığır derisi, kuzu yünü, pelerin, klyafet, gümüş tel, ipek ve küçük bir miktar 
baskılı patiska; Fransa'dan kıyafet, halı, çivi, şeker, kahve, çarşaf, deri, çelik, mum, hırdavat, alkol alınmıştır. Avusturya'dan tırpan, sigara kâğıdı, kıyafet, fes, çam eşya, çanak çömlek, yazı kâğıdı, kalay; Almanya'dan petrol, alkol; Almanya'dan bardak; İtalya'dan kibrit, İsviçre'den tülbent ve fular ithal edilmiştir.

Erzurum Vilayeti'ne Bitlis, Muş, Sïrt, Diyarbakır, Mardin, Halep, Mamuretü'l-Aziz, Trabzon, Samsun, Rize, Erzincan, Arapkir, Ayntab, Bağdat, Karahisar, Palu ve Tokat'dan ürünler alınmıştır. İç ticaret kapsamında Erzurum pazarında en fazla ürün bulunduran vilayet, Bitlis Vilayetidir. Bitlis Vilayeti'nden alınan başlıca ürünler; tiftik kumaşı, mazı, sakız, keçi derisi, balmumu, renkli pamuk, boya kökü, palamut, kurutulmuş meyve, tereyağı, bal, kürk, acı çehre, tütün, tiftik, kitre, mazıdır. Van Vilayeti’nden aba, yün, tiftik kumaşı, tiftik, keçi derisi, hayvan postu, mazı, kürk; Trabzon Vilayeti’nden tütün, kurutulmuş meyve, sarımsak, portakal, liman, sabun, zeytinyağı; Diyarbakır ve Mardin'den sabun, deri, manusa, ipek, pirinç, kurutulmuş meyve, mazı, kürk, tereyağı; Halep Vilayeti'nden ipek, sabun, manusa, baskılı yazma, boyalı ipek, mavi boyalı pamuk; Harput'tan ipek, şarap, kurutulmuş meyve, ham pamuk; Erzincan'dan manusa, kumaş bazı öteberi; Arapkir'den manusa; Ayntap'dan Manusa; Tokat'tan manusa; Rize'den keten; Bağdat'tan hurma; Karahisar'dan şap, Palu'dan sapan ve kurutulmuş meyve alınmıştır. Erzurum Vilayeti’nden diğger vilayetlere satılan ürünler pastırma, inek ve öküz, koyun, at, eyer takımı, iç yağı, buğdaydır.

Çalışmada temel kaynak olarak İngiliz Konsolosluk belgeleri kullanılmıştır. Konsoloslar, raporlarında geçen bilgilerin büyük bir kısmını Erzurum Gümrük İdaresi ile yerel hükümetten tedarik etmişlerdir. Ayrıca konsoloslar, mevcut pazar durumu ile ilgili kendi gözlem ve deneyimlerine ve yakın vilayetlerdeki konsoloslardan iç ticaret ve dış ticaret hacmiyle ilgili elde ettikleri bilgilere yer vermişlerdir. 


\section{KAYNAKLAR}

\section{A. Arşiv Belgeleri}

\section{İngiliz Arşivi Belgeleri (The National Archieves)}

F.O. (Foreign Office) 195/1450, No. 1/1, William Everett'den G.H. Wyndham'a, 31 Temmuz 1883.

F.O. 195/1450, No. 21, Harry Charles Augustus Eyres'den G.H. Wyndham'a, 12 Temmuz 1883.

F.O. 195/1450, No. 21/1, Harry Charles Augustus Eyres'den G.H. Wyndham'a, 12 Temmuz 1883.

F.O. 195/1481, No.1, William Everett'den Dufferin'e, 10 Haziran 1884.

F.O. 195/1552, No. 6/1, George Pollard Devey'den Sir E. Thornton'a, 16 Temmuz 1886.

F.O. 195/1552, No. 6 (Annex A), George Pollard Devey’den Sir E. Thornton'a, 16 Temmuz 1886.

F.O. 195/1552, No. 6 (Annex B), George Pollard Devey'den Sir E. Thornton'a, 16 Temmuz 1886.

\section{B. Salnâmeler}

Salnâme-i Vilâyet-i Erzurum, H. 1293 (M. 1876), Def'a 7.

Salnâme-i Vilâyet-i Erzurum, H. 1299 (M. 1882), Def’a 9.

\section{Kitaplar}

Açba, Sait, Osmanlı Devletinin Dış Borçlanması (1854-1914), Akü Yayınları, Afyon 1995.

Devellioğlu, Ferit, Osmanlıca-Türkçe Ansiklopedik Lûgat, 17. bs., Aydın Kitabevi, Ankara 2000.

Karataş, Yakup, Sultan II. Abdülhamid Dönemi’nde Erzurum (Sosyal, Ekonomik, İdarî ve Demografik Yapr), Doktora Tezi, Atatürk Üniversitesi Sosyal Bilimler Enstitüsü, Erzurum 2010. 
Lewis, Bernard, Modern Türkiye’nin Doğuşu, Türk Tarih Kurumu Yayınları, Ankara 1998.

Mahmud Celaleddin Paşa, Mir'ât-ı Hakîkat, haz. İsmet Miroğlu, c. II, Berekât Yayınları, İstanbul 1983.

The Foreign Office List: Forming a Complete Diplomatic and Consular Handbook for 1870, Compiled by Edward Hertslet, C.B., Thirty-sixth Publication, London.

The Foreign Office List: Forming a Complete Diplomatic and Consular Handbook for 1886, Compiled by Edward Hertslet, G.B., Fifty-ninth Publication, London.

The Foreign Office List: Forming a Complete Diplomatic and Consular Handbook for 1887, Compiled by Edward Hertslet, C.B., Sixtieth Publication, London.

The Foreign Office List: Forming a Complete Diplomatic and Consular Handbook for 1889, Compiled by Edward Hertslet, G.B., Sixty-second Publication, London.

Temizgüney, Firdevs, Erzurum'a Demiryolunun Gelişi, Yüksek Lisans Tezi, Atatürk Üniversitesi Sosyal Bilimler Enstitüsü, Erzurum 2008.

Uçarol, Rifat, Siyasi Tarih (1789-2010), 8. Baskı, Der Yayınları, İstanbul 2010.

Yakman, Ahmet, 163 Nolu Arapkir Şer’iye Siciline Göre Arapkir, Yüksek Lisans Tezi, İnönü Üniversitesi Sosyal Bilimler Enstitüsü, Malatya 2015.

\section{Makale ve Ansiklopedi Maddeleri}

Ak, Mehmet, Osmanlı Devleti’nde Veba-i Bakarî (Sığır Vebası)", OTAM, S. 39, Bahar 2016, ss. 215-240.

Akbulut Özpay, Gülpınar, "Bakü-Tiflis-Kars Demiryolu ve Türkiye Açısından Jeopolitik Önemi”, Marmara Coğrafya Dergisi, S. 37, Ocak 2018, ss. 103-111.

Bay, Abdullah, "Limanı Olan Bir Kasabadan Liman Kendine: Batum Şehri (1830-1905)", Türkiyat Mecmuası, c. 26/1, 2016, ss. 61-80.

Darkot, Besim, "Erzurum", İslam Ansiklopedisi, Cilt: IV., Milli Eğitim Bakanlığı Yayınları, Eskişehir 1997, ss. 340-345.

Demir Görür, Emel, “İngiltere’nin Diyarbakır Konsolosu John George Taylor’ın Diyarbakır Eyaleti'ne Dair İthalat-İhracat İstatistikleri ve Değerlendirmeleri (1853-1863)", TAD, Cilt: 37, S. 64, 2018, ss. 323-346. 
Erim, Neşe, "18. Yüzyılda Erzurum Tuzlaları: Osmanlı Tüketim Malları Tarihine Bir Katkı”, A.Ü. Türkiyat Araştırmalan Enstitüsü Dergisi, S. 21, Erzurum 2003, ss. 219- 229.

Gürsel, Seyfettin, "Osmanlı Dıß̧ Borçları", Tanzimat'tan Cumhuriyete Türkiye Ansiklopedisi, Ed. Murat Belge, c. III, İletişim Yayınları, İstanbul 1985, ss. 679680.

İnalcık, Halil, "Erzurum", İslam Ansiklopedisi, Cilt: IV, Milli Eğitim Bakanlığı Yayınları, Eskişehir 1997, ss. 353-357.

Kaleli, Hüseyin, "19. Yüzyılda İan Transit Ticaret Yolu İçin Osmanlı-Rus Rekabeti”, Dumluprnar Üniversitesi Sosyal Bilimler Dergisi, S. 9, 2003, ss. 1-19.

Kallek, Cengiz, "Batman", Diyanet Vakfi Íslam Ansiklopedisi, Cilt: V, Türk Diyanet Vakfi Yayınları, İstanbul 1992, ss. 199-120.

Kallek, Cengiz, "Kile", Diyanet Vakfi İslam Ansiklopedisi, Cilt: XXV, Türk Diyanet Vakfi Yayınları, İstanbul 2002, ss. 568-571.

Kazgan, Haydar, "Düyun-1 Umumiye", Tanzimat'tan Cumhuriyet'e Türkiye Ansiklopedisi, Ed. Murat Belge, Cilt: III, İletişim Yayınları, İstanbul 1995, ss. 691-716.

Keskinkılıç, Erdoğan, "Bir Osmanlı Özelleştirme Modeli: Reji-Tütün İdaresi”, Liberal Dïsünce, Bahar 1999, ss. 151-155.

Keskinkılıç, Erdoğan, "Düyun-1 Umumiye İdaresi”, Türkler, Gilt: XIV, Yeni Türkiye Yayınları, Ankara 2002, ss. 371-380.

Küçük, Cevdet, Tevfik Ertüzün, "Düyun-1 Umumiyye", Diyanet Vakfi İslam Ansiklopedisi, Cilt: X, Diyanet Vakfi Yayınları, İstanbul 1994, ss. 58-62.

Küçük, Cevdet, "Erzurum”, DIA, Cilt: XI, Türk Diyanet Vakfi Yayınları, İstanbul 1995, ss. 321-329.

Kütükoğlu, Mübahat S., "Gümrük", Diyanet Vakfi İslam Ansiklopedisi, Cilt: XIV, Türk Diyanet Vakfi Yayınları, İstanbul 1996, ss. 263-268.

Önsoy, Rifat, "Muharrem Kararnamesi ve Düyûn-u Umumiye İdaresi”, Osmanh/ Iktisat, Cilt: III, Ed. Güler Eren, Yeni Türkiye Yayınları, Ankara 1999, ss. 400-414. 
Pamuk, Bilgehan, "Erzurum Gümrügü’nün Teşekkülü ve Tekâmülü (XVI-XVII Yüzylllar)", Belleten, Cilt: LXXVII, S. 279, Ağustos 2013, ss. 523-545.

Pamuk, Bilgehan, "İpekyolu Ticareti ve Erzurum", Tarih İncelemeleri Dergisi, c. XXII, S. 2, Aralık 2017, ss. 125-143.

Quataert, Donald, "Düyun-1 Umumiye'nin İstihdam Politikaları (1881-1909)", çev. Ahmet Fethi, Toplumsal Tarih, S. 79, Temmuz 2000.

Tekin, Ahmet, "Osmanlı Devleti Dış Borçlanması", Yeni Türkiye, S. 32, Mart-Nisan 2000.

\section{E. Süreli Yayınlar}

The London Gazette, Publication Date: 22 September 1882, Issue: 25149, Page: 4340 .

The London Gazette, Publication Date: 4 Ağustos 1885, Isuue: 25497, Page: 3599.

\section{H. Elektronik Kaynak}

Marjie Bloy, "British Currency Before 1971", http://www.victorianweb.org/ economics/currency.html (14.09.2018).

Cambridge Dictionary, https://dictionary.cambridge.org/tr/s\%C3\% B6zl\% C3\%BCk/ingilizcet $\% \mathrm{C} 3 \% \mathrm{BCrk} \% \mathrm{C} 3 \% \mathrm{~A} 7 \mathrm{e} / \mathrm{cwt}$ (11.12.2018)

https://dictionary.cambridge.org/tr/s\%C3\%B6zl\% $\% \mathrm{C} 3 \% \mathrm{BCk} /$ ingilizce/bushel $(13.11 .2018)$ 



\section{EKLER}

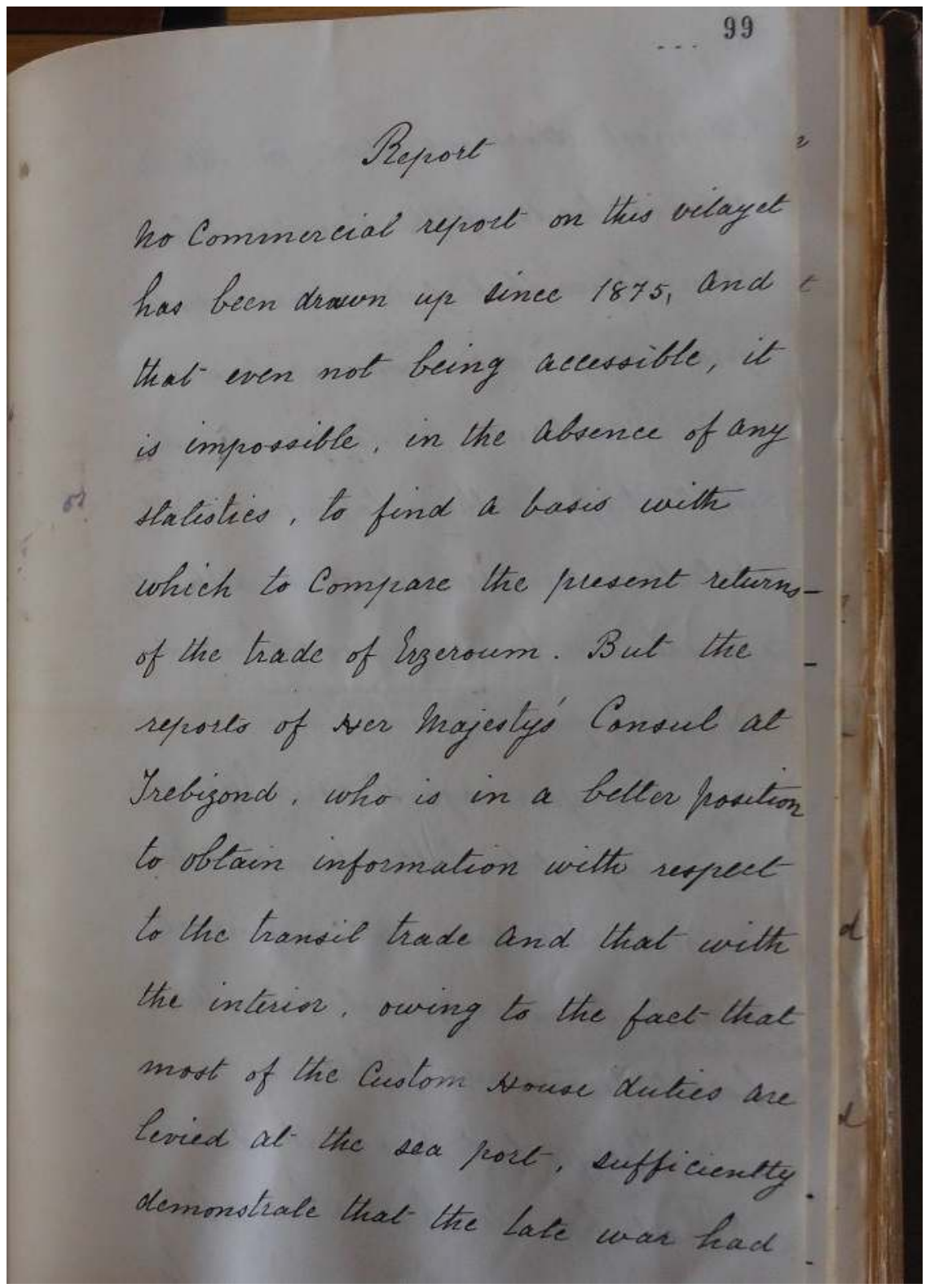

Ek-1: Konsolos Harry Charles Augustus Eyres’in 1883 yılı raporundan örnekler 


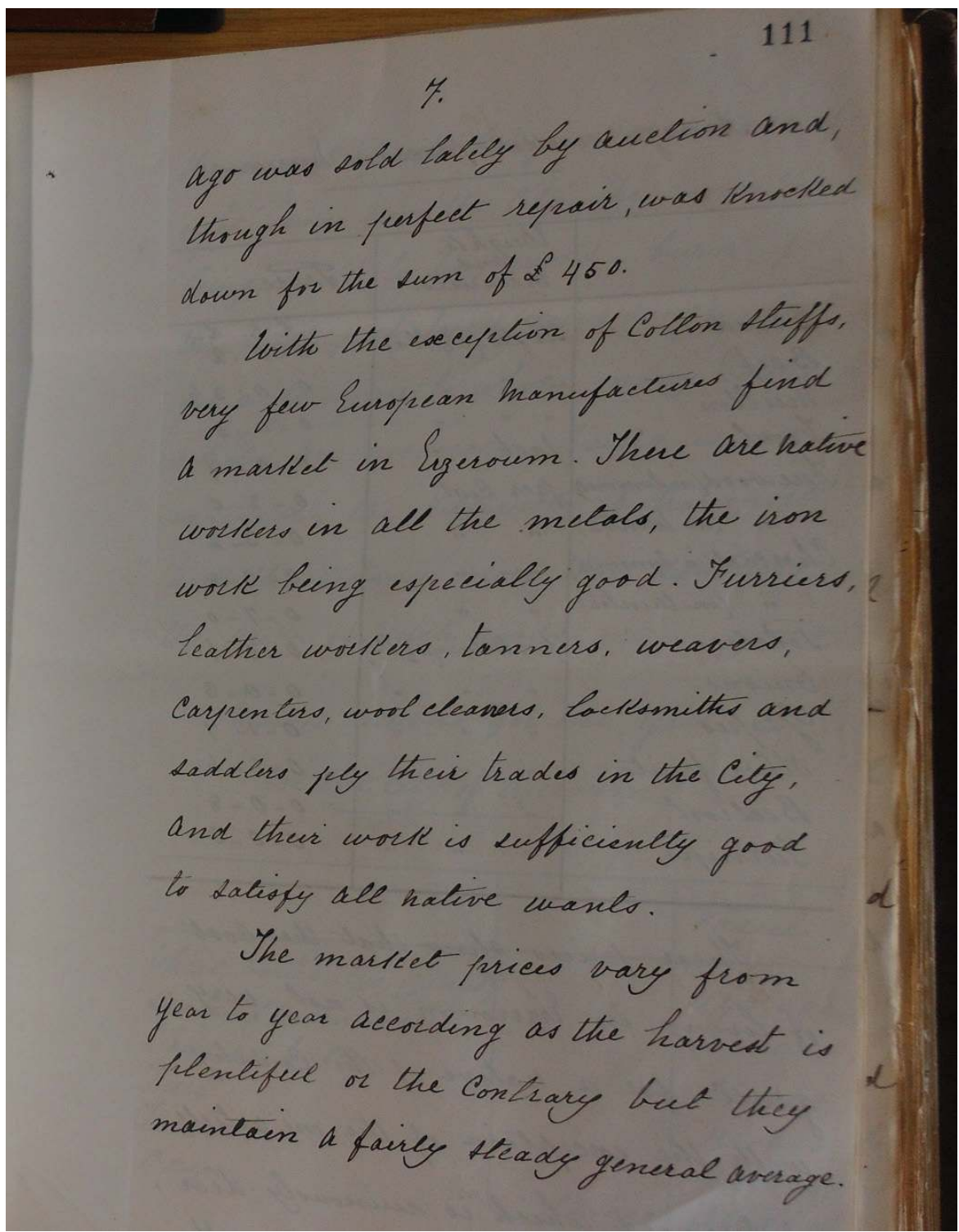

Ek-1 (devam): Konsolos Harry Charles Augustus Eyres'in 1883 yılı raporundan örnekler TNA., F.O. 195/1450, No. 21/1, Harry Charles Augustus Eyres'den G.H. Wyndham'a, 12 Temmuz 1883, s. 99,111. 


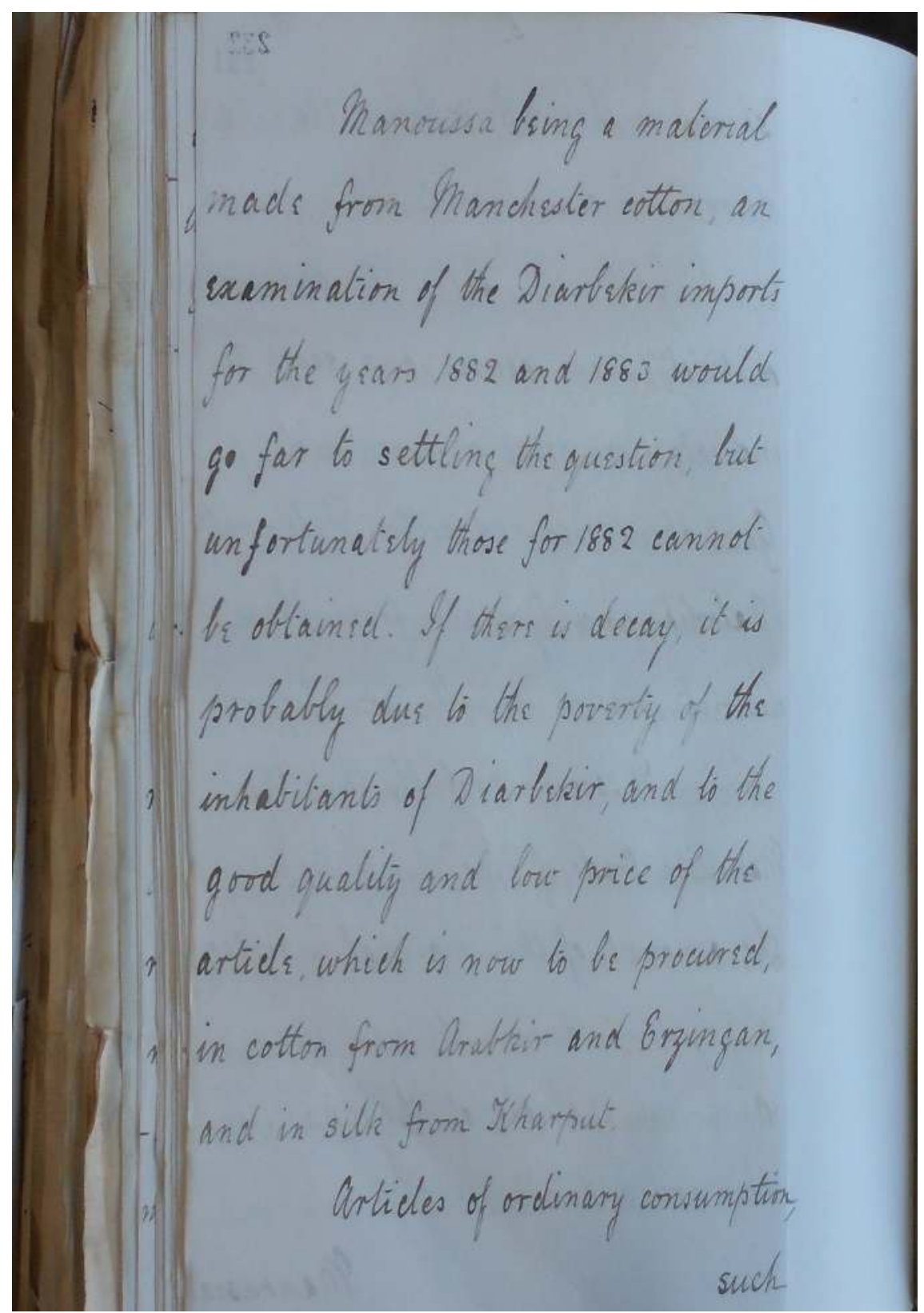

Ek-2: Konsolos William Everett’in 1884 yılında yazdığı raporundan örnekler 


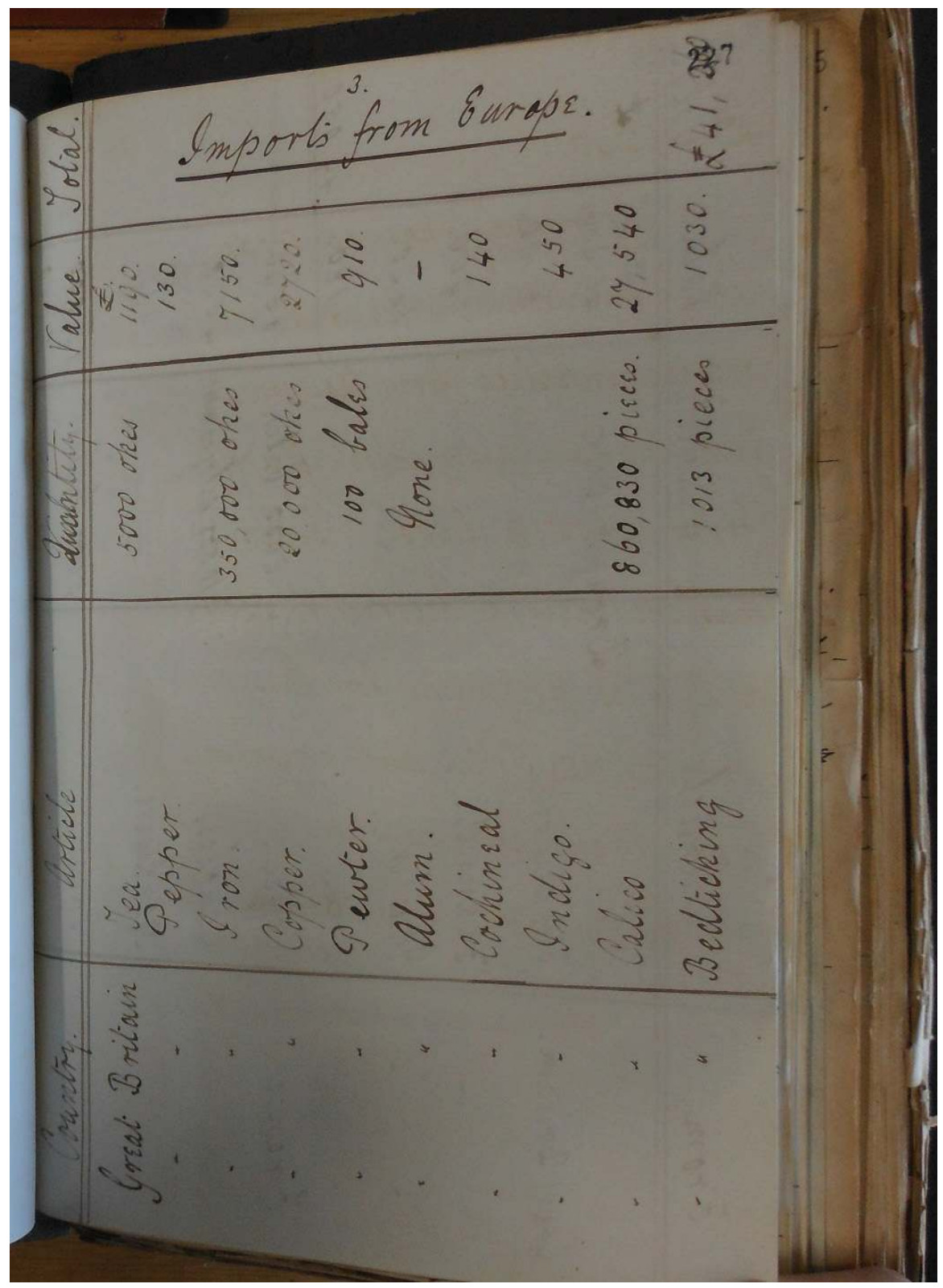

Ek-2 (devam): Konsolos William Everett'in 1884 yılında yazdığı raporundan örnekler 


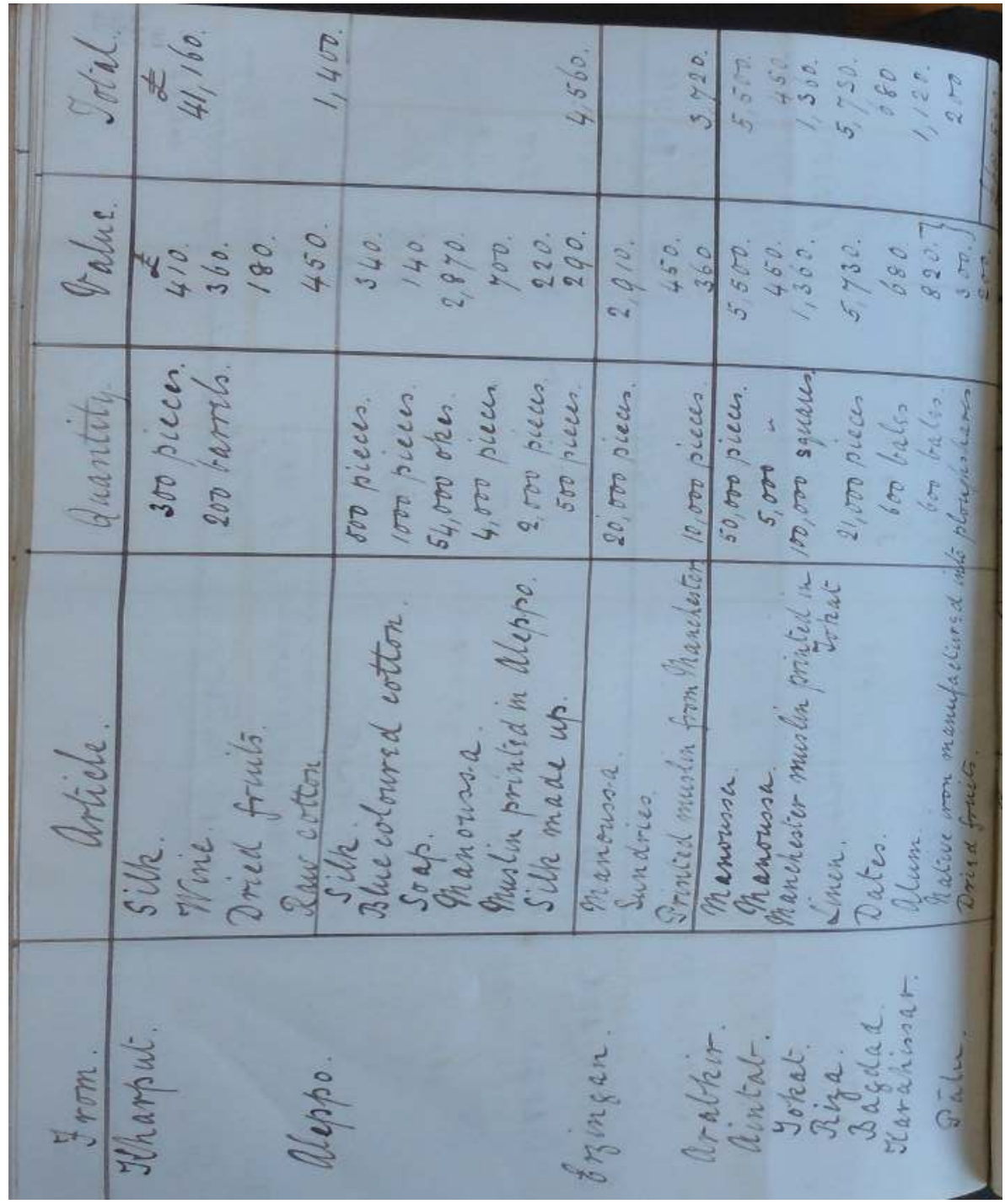

Ek-2 (devam): Konsolos William Everett'in 1884 yılında yazdığı raporundan örnekler

TNA., F.O. 195/1481, No.1, William Everett'den Dufferin'e, 10 Haziran 1884, s. 227-232-235. 
Emel Demir Görür

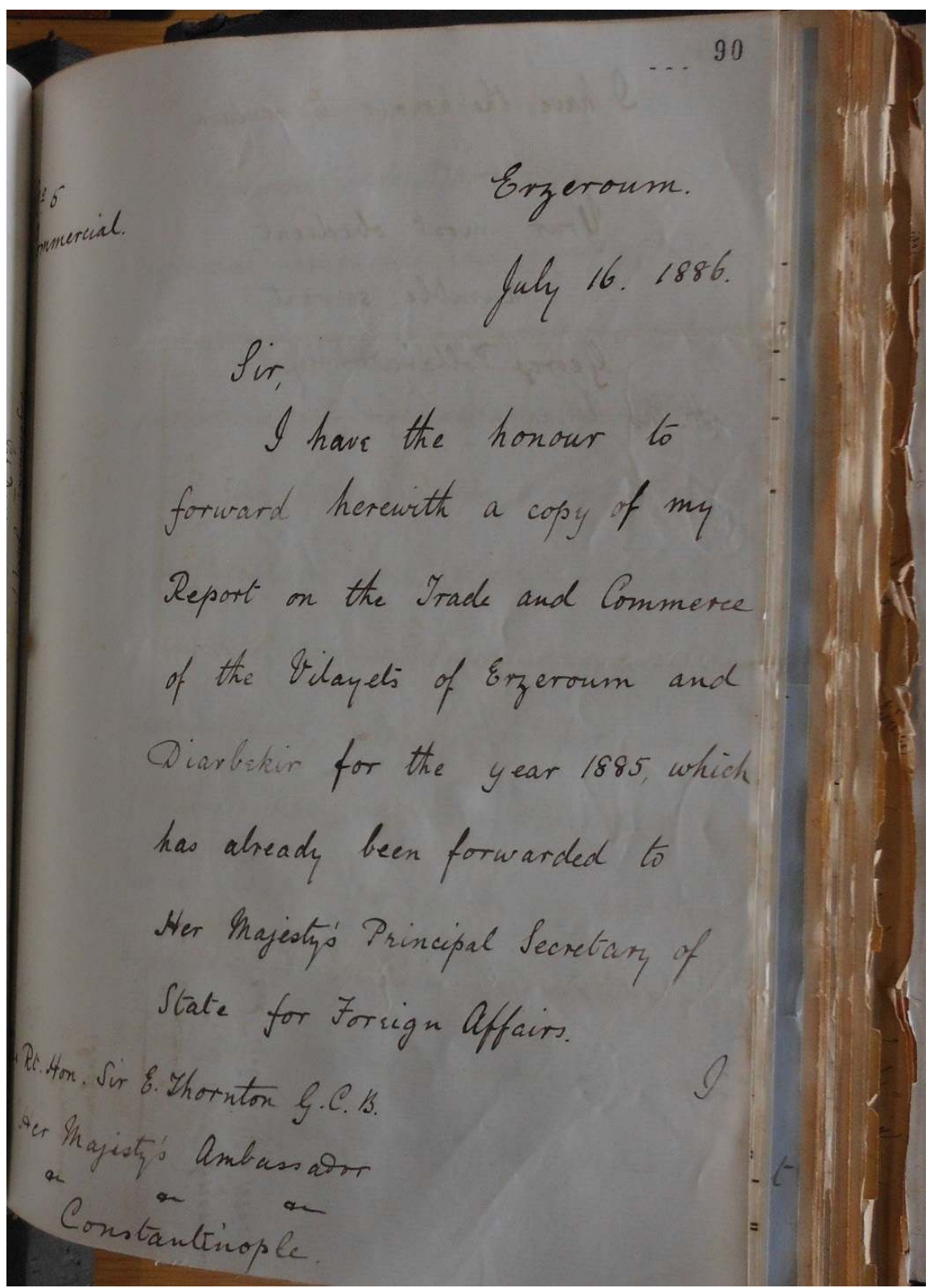

Ek-3: Konsolos George Pollard Devey’in 1886 yılında yazdığı raporundan örnekler 


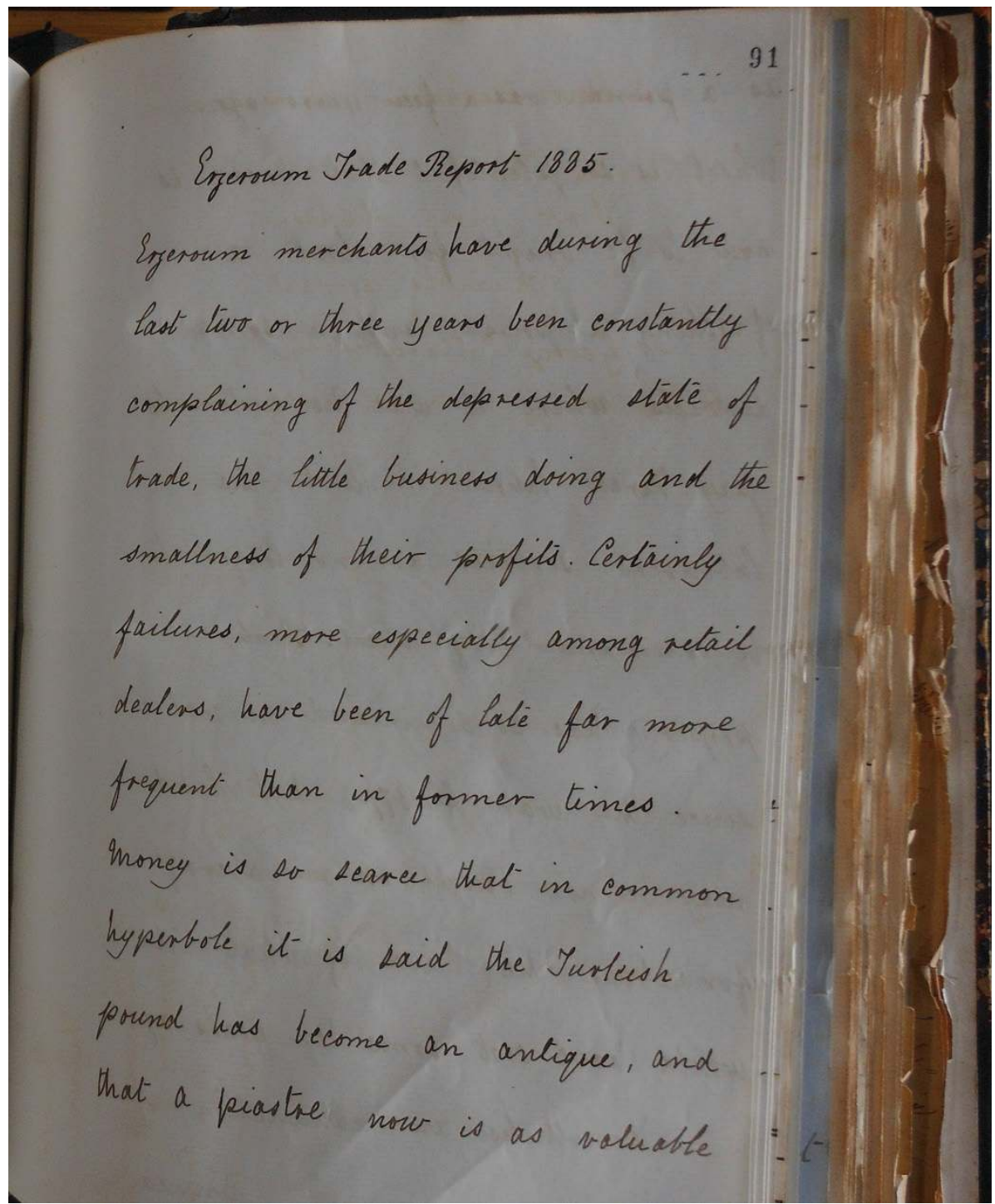

Ek-3 (devam): Konsolos George Pollard Devey’in 1886 yılında yazdığı raporundan örnekler

TNA., F.O. 195/1552, No. 6 (Annex B), George Pollard Devey'den Sir E. Thornton'a, 16 Temmuz 1886, s.90-91. 
